\title{
EXCHANGE RATE VOLATILITY AND GROWTH IN EMERGING EUROPE AND EAST ASIA
}

\author{
GUNTHER SCHNABL
}

\author{
CESIFO WORKING PAPER NO. 2023 \\ CATEGORY 6: MONETARY POLICY AND INTERNATIONAL FINANCE \\ JUNE 2007
}

Presented at CESifo Area Conference on Macro, Money \& International Finance, February 2007

An electronic version of the paper may be downloaded

- from the SSRN website:

wWw.SSRN.com

- from the RePEc website:

www.RePEc.org

- from the CESifo website:

www.CESifo-group.de 


\title{
EXCHANGE RATE VOLATILITY AND GROWTH IN EMERGING EUROPE AND EAST ASIA
}

\begin{abstract}
The paper investigates the impact of exchange rate volatility on growth in Emerging Europe and East Asia. Exchange stability has been argued to affect growth negatively as it deprives countries from the ability to react in a flexible way to asymmetric real shocks and may enhance the probability of speculative capital inflows and overheating. In contrast, exchange rate stability can be argued to affect growth in emerging market economies positively because transaction costs for international trade decline, uncertainty for international capital flows is less and macroeconomic stability is enhanced. Cross country panel estimations provide evidence for a negative impact of exchange rate volatility on growth both in Emerging Europe and East Asia.
\end{abstract}

JEL Code: F43, F31, E42.

Keywords: exchange rate regimes, growth, boom-and-bust cycles, Emerging Europe, East Asia.

\author{
Gunther Schnabl \\ Leipzig University \\ Marschnerstr. 31 \\ 04109 Leipzig \\ Germany \\ schnabl@wifa.uni-leipzig.de
}

I thank the participants of the CESifo Area Conference on "Macro, Money, International Finance" for very useful comments and Andreas Hoffmann for excellent research assistance. 


\section{Introduction}

After the 1997/98 Asian crisis a controversial discussion about the pros and cons of exchange rate stabilization has emerged. Proponents of flexible exchange rates have argued that fixed exchange rates encourage speculative capital inflows, moral hazard and overinvestment. The economic policy implication is to pursue fully (more) flexible exchange rate regimes (Fischer 2001). In contrast proponents of fixed exchange rates have stressed the positive impact of exchange rate stability on the economic performance of the East Asian economies. McKinnon and Schnabl (2003, 2004a) emphasize the role of low transaction costs for international and intra-regional trade and capital flows.

In the decade after the Asian crisis Emerging Europe and East Asia have taken different directions on the path towards more (less) exchange rate stability. Emerging Europe, i.e. the central, eastern and south-eastern European countries have further strengthened their institutional and economic linkages with the European Union. This has led to a wider use of the euro as an invoicing, vehicle, banking, pegging, intervention and reserve currency and more exchange rate stability against the euro (ECB 2006, Kamps 2006). In contrast, in East Asia post-crisis exchange rate volatility against the US dollar steadily declined up to the year 2005, but has increased since then. China and many other East Asian countries seem to follow (hesitantly) international policy recommendations in favour of more exchange rate flexibility.

What will be the impact of the different exchange rate strategies on economic growth in the two regions? Up to the Asian crisis, an - for emerging market economies - exceptional degree of the international and intra-regional exchange rate stability has been regarded as an important pillar of the East Asian miracle (World Bank 1993, McKinnon 2005). Now Asia seems to move towards (more) exchange rate flexibility (against the dollar) average regional growth has declined. In contrast, Emerging Europe has experienced high exchange rate volatility during most of the 1990s. Since exchange rates have started to stabilize in the late 1990s growth rates are high.

Does this imply that ceteris paribus the long-run growth perspective will be better for Emerging Europe than for East Asia? Or do stable exchange rates against the euro encourage speculative capital inflows which in the long-run will deteriorate Emerging Europe's growth performance? Previous research on the impact of exchange stability on growth has tended to find weak evidence in favour of a positive impact of exchange rate stability on growth. For large country samples such as by Ghosh, Gulde and Wolf (2003) there is weak evidence that exchange rate stability af- 
fects growth in a positive or negative way. The panel estimations for more than 180 countries by Edwards and Levy-Yeyati (2003) find evidence that countries with more flexible exchange rates grow faster. Eichengreen and Leblang (2003) reveal a strong negative relationship between exchange rate stability and growth for 12 countries over 120 years. They conclude that the results of such estimations strongly depend on the time period and the sample.

While many previous studies have chosen very large samples to increase the robustness of the estimation process we approach the question from a different angle. We test for the impact of exchange rate volatility on growth for two groups of countries in the economic catch-up process which have widely dismantled capital controls. This allows us to control for the impact of capital controls which facilitate exchange rate stability but which are detrimental for the growth performance. The comparison of two groups of countries which have pursued different exchange rate strategies at different points of time are expected to yield enough heterogeneity in the crosscountry panel to isolate a significant impact of exchange rate volatility on growth.

Building upon De Grauwe and Schnabl (2005a) and Schnabl (2006), we perform GLS panel estimations for 17 countries in Emerging Europe and 9 East Asian countries. In addition we use 10 South American countries as a control group. The results provide evidence in favour of a robust negative relationship between exchange rate volatility and growth.

\section{Regional Trends in Exchange Rate Volatility}

Since the late 1970s the East Asian emerging economies ${ }^{1}$ kept their exchange rates tightly pegged to the US dollar (McKinnon and Schnabl 2004a). This common dollar peg not only maintained exchange rate stability against the US as the most important (single) trading partner, but also ensured an exceptional degree of intra-regional exchange rate stability. McKinnon (2005) argues that this "informal dollar standard" was the basis for a high degree of intra-regional partition of labour and export-oriented growth. Both factors are linked to the East Asia economic miracle (World Bank 1993). China joined the East Asian dollar standard in 1994 when it pegged its exchange rate tightly to the dollar.

The intra-regional exchange rate stability in East Asia was high until the 1997/98 Asian crisis interrupted the fast economic catch-up. Post-crisis exchange rate stability against the US re-

\footnotetext{
Hong Kong, Indonesia, Korea, Malaysia, Philippines, Singapore, Taiwan and Thailand.
} 
approached the pre-crisis levels up to the year 2004 (McKinnon and Schnabl 2004b). Since the year 2005 East Asian exchange rate volatility against the dollar has increased (Figure 1). For instance, China and Malaysia have loosened their tight dollar pegs and have allowed for gradual appreciations of their currencies since then. Korea has allowed for an unprecedented degree of exchange rate volatility against the dollar. This may reflect international policy recommendations in favour of more exchange rate flexibility in East Asia (Fisher 2001).

Figure 1: Exchange Rate Volatility in Emerging Europe (against the Euro) and in East Asia (against the Dollar)

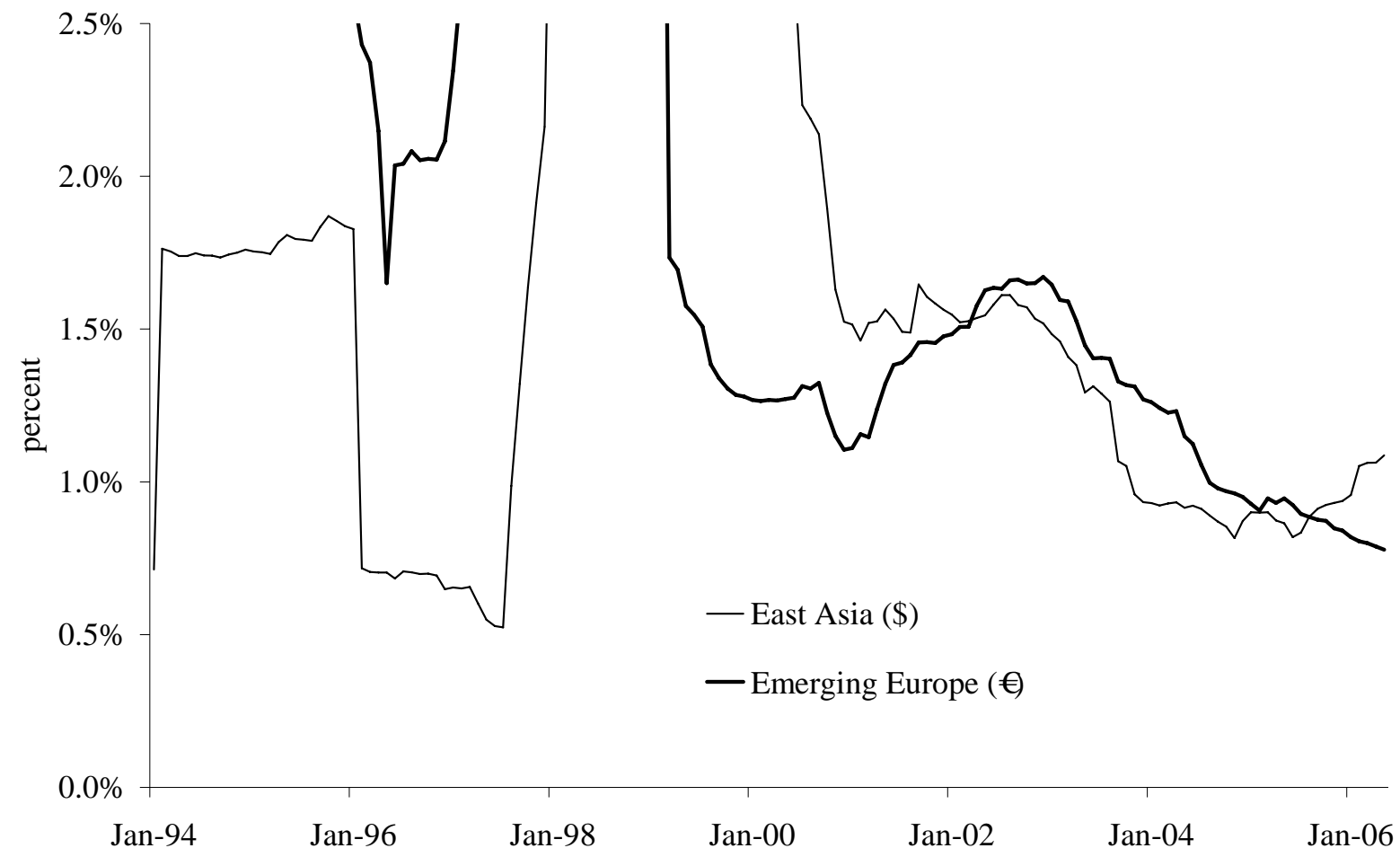

Source: IMF: IFS. Volatility defined as two year rolling standard deviations of monthly percent changes against the respective anchor currency. Country groups as defined in Table 1 are calculated as arithmetic averages. The German mark represents the euro before January 1999.

While East Asia seems to move from exchange rate stability to (more) exchange rate flexibility, Emerging Europe is moving into the opposite direction. During most of the 1990s exchange rate volatility in the region has been high for two reasons. First, most of the countries in central, eastern and south-eastern Europe experienced a high degree of macroeconomic instability and depreciations of their currencies. Second, various types of exchange rate pegs (hard pegs, downward crawling pegs, currency baskets) had different anchors. Some countries pegged their currencies to the German Mark (Estonia, Croatia) others to the dollar (Lithuania, Romania) or currency baskets 
(Latvia, Hungary, Czech Republic). The outcome was high intra-regional exchange rate instability which can be linked to weak intra-regional trade linkages.

Since the late 1990s exchange rate stability in Emerging Europe has increased steadily. The accession of the central, eastern und south-eastern European countries to the European Union $^{2}$ required macroeconomic stabilization which led to a substantial decline in exchange rate volatility. Although some countries such as Poland and the Czech Republic moved to more exchange rate flexibility since the late 1990s intra-regional exchange rate stability increased as many countries re-pegged their currencies from the dollar to the euro (e.g. Lithuania, Bulgaria, Romania) or substituted currencies baskets by unilateral euro pegs (e.g. Latvia, Hungary).

The redirection of the exchange rate targets towards the euro has both institutional and economic reasons. From an institutional perspective all countries (except the UK and Denmark) which join the European Union have to join - sooner or later - the European Monetary Union (EMU). From an economic perspective the integration into the European goods and capital markets makes exchange rate stability against the euro beneficial as transaction costs decline for an increasing share of international goods and capital flows. Also non-EU countries such as Albania, Croatia or the FYR Macedonia peg their currencies more or less tightly to the euro. Among the European countries, only Turkey maintains (partially) a (loose) dollar peg.

Figure 2 shows the different degrees of exchange rate volatility for Emerging Europe and East Asia both against the euro (before 1999 DM) and the dollar (unweighted averages). The upper panel depicts exchange rate volatility for Emerging Europe. During most of the 1990s exchange rate volatility was high both against the dollar and the German mark. Since the late 1990s exchange rate volatility against the euro has become significantly lower than against the dollar and has steadily declined. In East Asia as shown in the lower panel of Figure 2 exchange rate volatility against the dollar has been very low compared to exchange rate volatility against the euro (German mark before 1999) since the early 1980s except for the 1997/98 crisis period. Since the year 2005, exchange rate volatility has started to rise.

2 Besides the countries which have already joined the European Union, Turkey, Croatia and the FYR Macedonia have the status of candidate countries, Albania, Bosnia-Herzegovina, Serbia and Montenegro are potential candidate countries. 


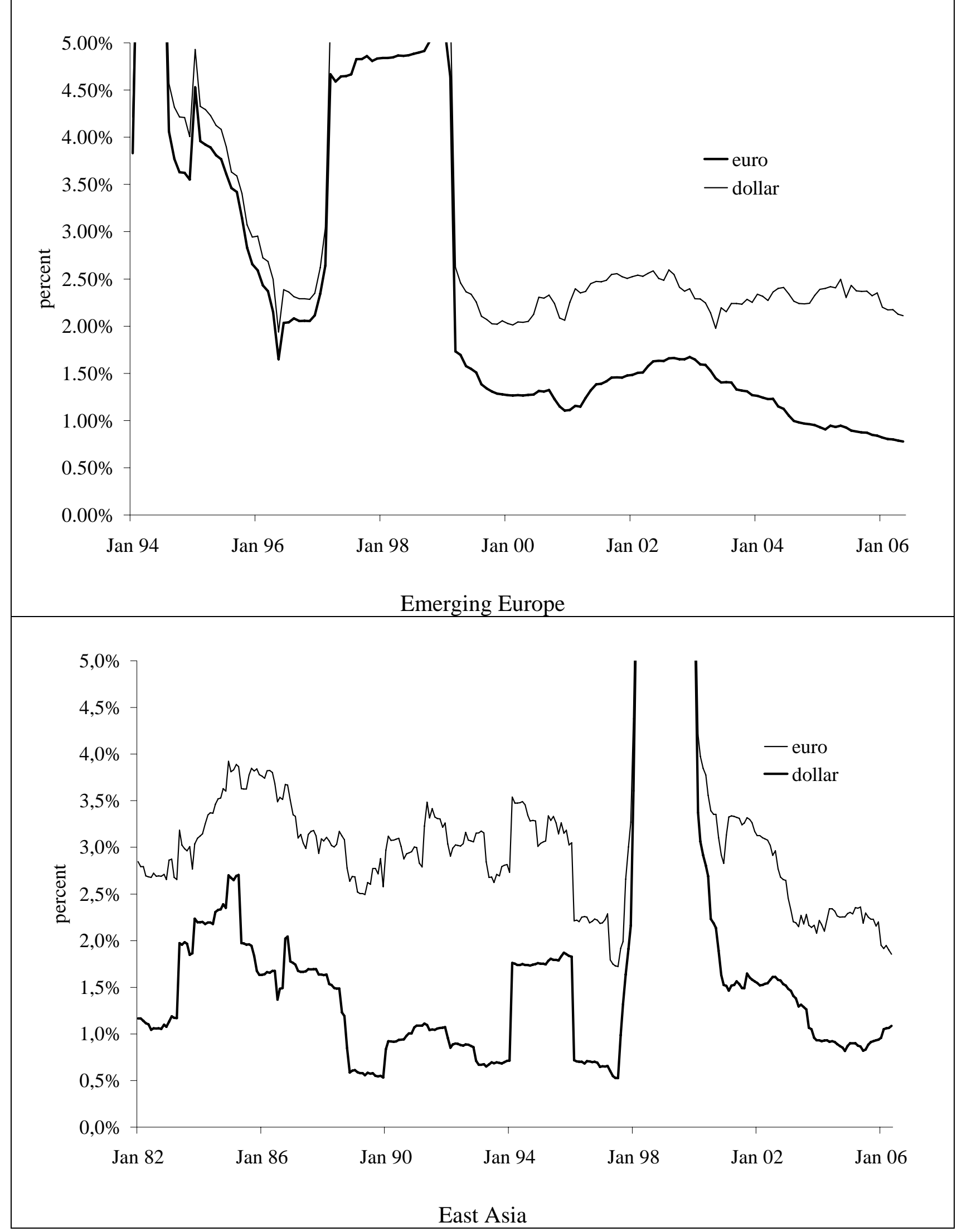

Source: IMF: IFS. Volatility defined as two year rolling standard deviations of monthly percent changes. Country groups calculated as arithmetic averages. The country groups are defined in Table 1. The German mark represents the euro before January 1999. 
Figure 3 provides an overview over the growth performance of the two regions. Growth is defined as the arithmetic average of the countries represented in the respective group as listed in Table 1. We observe a very high level of growth for the East Asian countries up to the Asian crisis. After the crisis the average growth in East Asia has picked up again, but has declined compared to the pre-crisis period. In contrast, in Emerging Europe growth was low at the beginning of the transformation process and jumped to a high level during the second half the late 1990s. This may suggest a negative relationship between exchange rate volatility and growth.

Figure 3: Real GDP Growth in Emerging Europe and East Asia

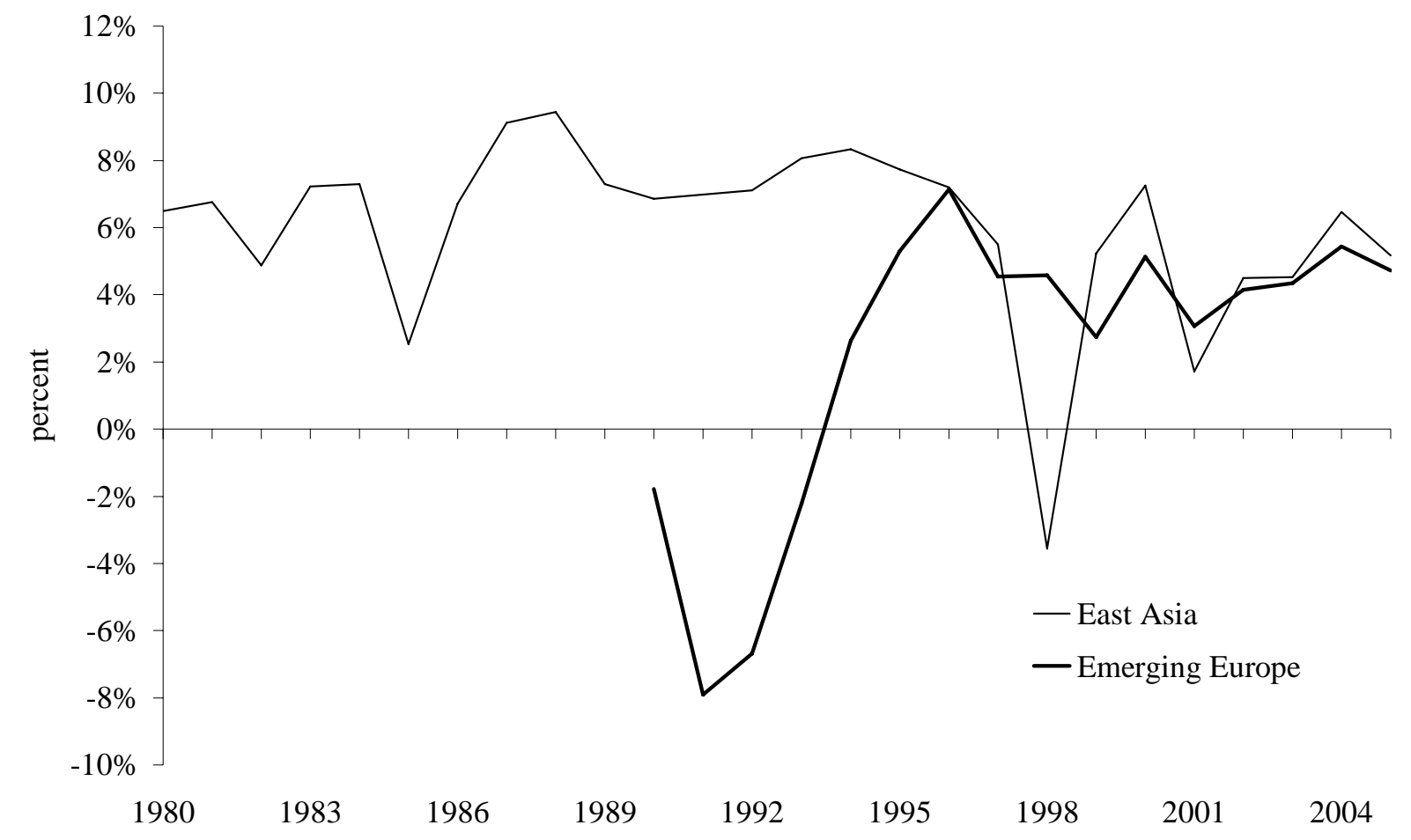

Source: IMF. Arithmetic averages.

\section{Theoretical Evidence}

The increasing degree of exchange rate stability in Emerging Europe and the (past) high degree of exchange rate stability in East Asia pose the question of why emerging market countries stabilize exchange rates. The effects of the exchange rate volatility on growth can be seen as a comprehensive measure of the benefits and costs of exchange rate stabilization. The following section surveys the role of asymmetric shocks, international trade and international capital markets as the most important transmission channels from exchange rate volatility (stability) to growth. 


\subsection{Asymmetric shocks}

Flexible exchange rates have been regarded as an important tool to cope with asymmetric (real) shocks (Meade 1951, Friedman 1953). The reason is that under fixed exchange rate regimes real exchange rate adjustments have to be carried out through relative price and productivity changes which in a world of price and wage rigidities are slow and costly. The outcome is a lower growth performance.

Mundell's (1961) seminal paper on optimum currency areas (OCA) extended the argument to a monetary union. Interpreting monetary and exchange rate policies as Keynesian instruments of adjustment, Mundell (1961) argued that shock absorption within a heterogeneous group of countries is easier if monetary and exchange rate policies remain independent. In particular for country groups with rigid labour markets and low international labour mobility, monetary autonomy was regarded as crucial. Today, Mundell’s (1961) OCA theory remains the most important theoretical framework to analyse the pro and cons of EMU enlargement (Fidrmuc and Korhonen 2006).

In contrast, McKinnon (1963) emphasized the benefits of fixed exchange rate regimes for small open economies in the face of nominal shocks. Assuming that for small open economies the international price level is given and traded goods make up a high share of the domestically consumed goods, exchange rate stability ensures domestic price stability. The welfare effect of stable exchange rates originates in macroeconomic stability which provides a favourable environment for investment, consumption and growth. From this perspective, as acknowledged by Mundell (1973a, 1973b) in later works, monetary and exchange rate policies are regarded as a source of uncertainty and volatility in small open economies. Growth is stimulated when exchange rate fluctuations are smoothed.

\subsection{International Trade}

The welfare gains from the international partition of labour are widely acknowledged. The economic policy implication is to remove exchange rate volatility to foster trade and higher growth.

The impact of exchange rate volatility on trade among two or a group of countries has both a micro- and macroeconomic dimension. From a microeconomic perspective exchange rate volatility - for instance measured as day-to-day or week-to-week exchange rate fluctuations - is associated with higher transactions costs because uncertainty is high and hedging foreign exchange risk is costly. Indirectly, fixed exchange rates enhance international price transparency as consumers can 
compare prices in different countries more easily. If exchange rate volatility is eliminated, international arbitrage enhances efficiency, productivity and welfare. These microeconomic benefits of exchange rate stabilization have been a pivotal motivation of the European (monetary) integration process (European Commission 1990) which can be regarded as the most comprehensive and advanced approach to eliminate intra-regional exchange rate fluctuations.

The macroeconomic dimension arises from the fact that long-term exchange rate fluctuations for instance measured as monthly or yearly changes of the exchange rate level - affect the competitiveness of domestic export and import competing industries. In specific in small open economies the growth performance is strongly influenced by long-term fluctuations of the exchange rate level. Even comparatively closed economies such as the euro area and Japan are sensitive to large exchange rate swings, in particular in the case of appreciation. McKinnon and Ohno (1997) show for Japan that since the early 1970s - when the yen became flexible against the dollar - growth was negatively influenced by the appreciation of the Japanese currency.

McKinnon and Schnabl (2003) argue for the small open East Asian economies, that the fluctuations of the Japanese yen against the US dollar strongly affected the growth performance of the East Asian tiger economies. They identify trade with Japan and competition in third markets (US) as crucial transmission channels. Before 1995 the appreciation of the Japanese yen against the dollar enhanced the competitiveness of the smaller East Asian economies who kept their exchange rates pegged to the dollar. Economic growth in the region accelerated. Then, the strong deprecation of the yen against the dollar from 1995 into 1997 slowed down growth in Japans small neighbouring countries, contributing to the 1997/98 Asian crisis.

Although the short-term and long-term exchange rate swings can strongly affect the growth performance of open economies through the trade channel the empirical evidence in favour of a systematic positive (or negative) effect of exchange rate stability on trade (and thereby growth) has remained mixed (IMF 1984, European Commission 1990). Bacchetta and van Wincoop (2000) find based on a general equilibrium framework that exchange rate stability is not necessarily associated with more trade. Gravity models have been used as frameworks to quantify the impact of exchange rate stability on trade and growth in particular in the context of a monetary union. While the size of the coefficient by Frankel and Rose (2002) seems to exaggerate the trade effects of a monetary union, Micco, Stein and Ordoñez (2003) find that in its early years the European Monetary Union has increased trade by up to $16 \%$. 


\subsection{Capital Markets}

Capital markets have been playing an increasing role in the discussion about exchange rate stabilization and growth since the Asian crisis (Eichengreen and Hausmann 1999, McKinnon and Schnabl 2004a, De Grauwe and Schnabl 2005a, Aghion et al. 2006). The impact of exchange rates on economic growth via capital markets has both a short-term (microeconomic) and a longterm (macroeconomic) dimension.

From a short-term perspective, fixed exchange rates can foster economic growth by a more efficient international allocation of capital when transaction costs for capital flows are removed (McKinnon 1973). If international capital market segmentations are dismantled debtors in high yield emerging market economies benefit from a substantial decline in interest rates due to investment from low yield developed capital markets (Dornbusch 2001). The authorities in the emerging market debtor countries have an incentive to maintain capital inflows by dismantling capital controls and by providing an efficient financial supervision (Mehl, Vespro and Winkler 2005).

From a more long-term perspective, fluctuations in the exchange rate level constitute a risk for growth in emerging markets economies as they affect the balance sheets of banks and enterprises of which foreign debt tends to be denominated in foreign currency (Eichengreen and Hausmann 1999) Sharp depreciations inflate the liabilities in terms of domestic currency thereby increasing the probability of default and crisis. In debtor countries with highly euroized (dollarized) financial sectors, the incentive to avoid sharp exchange rate fluctuations is even stronger (Aghion et. al. 2006). Maintaining the exchange rate at a constant level, in particular preventing sharp depreciations, is equivalent to maintaining growth (McKinnon and Schnabl 2004a).

\subsection{Boom-and-Bust-Cycles}

Although as shown above, fixed exchange rates can support growth in small open economies by encouraging (low interest rate) international capital inflows, speculative capital inflows into countries with shallow capital markets can contribute to excess volatility and crisis (Backé, Égert and Zumer 2007, Martin, Schuknecht and Vansteenkiste 2007).

\footnotetext{
${ }^{3}$ The impact of exchange rate fluctuations in the case of asset dollarization is explored by McKinnon and Schnabl (2004b).
} 
During the 1970s and 1980s crisis in emerging market economies was associated with unsound macroeconomic policies, in particular in Latin American countries. The interdependence of volatile macroeconomic policies and crisis is reflected in the first generation of crisis models (e.g. Krugman 1979). In contrast, the East Asian crisis economies provide an example for boom-andbust cycles which are driven by "good governance” in macroeconomic policies including fixed exchange rate strategies. Before the 1997/98 crisis the East Asian emerging tiger economies attracted international capital flows (inter alia) for two reasons. First, the East Asian economies pursued favourable macroeconomic polices, i.e. low inflation and low government deficits. Second, the fixed exchange regimes helped attracting international capital inflows as they provided implicit guarantees to reconvert investment at constant exchange rates against the dollar.

Both factors interact. To maintain fixed exchange rates in the long-term, macroeconomic stability and flexibility are required. In particular labour markets have to adjust to asymmetric shocks. Such good macroeconomic performance attracts capital inflows. Interest rates decline. Investment, consumption and growth accelerate. As tax incomes rise due to the buoyant domestic activity, governments can keep deficits low. Capital inflows are additionally accelerated if interest rates in the large capital markets are low. For instance, in the case of the East Asian emerging economies in the mid 1990s capital inflows were further accelerated by historically low interest rates in Japan which boosted carry trade and the hunt for yield in Japan's small East Asian neighbouring countries (Schnabl und Starbatty 1998).

The downside of virtuous circles of sound macroeconomic performance and capital inflows as observed in East Asia before the year 1997 is the threat of inflation. While in pre-crisis East Asia, consumer price inflation remained comparatively moderate, inflation rose above the level in the US as buoyant capital inflows were translated through foreign exchange intervention into monetary expansion. Given that exchange rates were kept - by and large - constant the East Asian currencies appreciated in real terms. Current account deficits and financial account surpluses increased. The foreign currency denominated external debt and the exposure of the banking sectors increased. ${ }^{4}$ Inflation became most visible in the real estate and stock markets where prices increased fast providing evidence of asset price bubbles and overheating.

In East Asia, the currency and financial crisis started with speculation against the dollar pegs which reflected rising concerns about the sustainability of the East Asian boom. The waves of 
speculation ended with the collapse of the dollar pegs of five East Asian crisis economies which rendered the banking sectors bankrupt. The outcome was severe recessions (Figure 3) which were further deepened by IMF austerity programs. The East Asian crisis was propagated to the other East Asian non crisis economies which were affected through several transmission channels such as trade, capital flows and FDI. The outcome for the East Asian non-crisis economies was most severe for Japan where the Asian crisis caused falling stock prices at the Tokyo stock exchange which finally cumulated in the Japanese financial crisis.

The lesson drawn from the currency attacks on the East Asian debtor economies was that the pre1997 system of “soft” dollar pegs itself was at fault (Fischer 2001). Before 1997, because of high risk premiums - which helped to sustain capital inflows when current account deficits increased the interest rates in the East Asian debtor economies were much higher than on dollar or yen assets. Domestic banks were tempted to accept low-interest dollar (or yen) deposits instead of relatively high-interest baht deposits. The temptation to risk foreign exchange exposure was all the greater because exchange rates were (softly) fixed.

The answer of if flexible exchange rates would reduce the risk of crisis is not straightforward and depends on the central bank's response to appreciation pressure. Let's assume a situation of strong capital inflows which are driven by both favourable macroeconomic conditions in the emerging market economy and low interest rates in the large industrialized countries. This would bring the currency of the emerging market economy under appreciation pressure. If the central banks allow for appreciation and if appreciation expectations become sustained, additional speculative capital inflows will be encouraged. ${ }^{5}$ Under such circumstances the likelihood increases that the central bank will intervene in foreign exchange markets against “excessive appreciation” and that the capital inflows will be translated into a rising money supply. Compared to a fixed exchange rate regime the monetary expansion may be larger because sustained appreciation expectations encourage additional capital inflows. The probability of overheating further rises.

Only if the central bank allows for "uncontrolled appreciation" of the domestic currency, the probability of crisis declines because the sharp appreciation of the domestic currency deteriorates the economic outlook. The negative impact of appreciation on growth will be particularly strong

4 Concerning the impact of the currency denomination of external debt and the probability of crisis see Eichengreen and Hausmann (1999) and McKinnon and Schnabl (2004a).

5 For countries in the economic catch-up process with inflation targeting frameworks the probability of appreciation is even higher due to the Balassa-Samuelson effect which implies a nominal appreciation if the inflation rate is kept close to the level of the reference economy (De Grauwe and Schnabl 2005b). 
in small open economies because the share of exports of GDP is high and domestic activity is comparatively small. From this perspective the price of a lower probability of crisis will be lower growth. ${ }^{6}$

The upshot is that the policy choice of fully flexible exchange rates will be difficult to politically defend. This is even more the case when GDP per capita is low (as currently in China) and if neighbouring countries with fixed exchange rate regimes experience high growth due to buoyant capital inflows. Discretionary foreign exchange intervention in times of appreciation becomes likely. This may imply that the central bank “jumps” between domestic targets of monetary policy making (for instance inflation targets) in times of a weak currency and exchange rate targets in times of a strong currency. ${ }^{7}$ The outcome would be more uncertainty with respect to monetary policy making which can be linked to higher risk premiums on interest rates and thereby lower growth (Schnabl 2006).

This leads to the long-term cost-benefit-analysis. Countries with fixed exchange rate regimes can better benefit from buoyant international capital inflows, but risk a higher probability of crisis. ${ }^{8}$ Emerging market economies with fully flexible exchange rate regimes won't be able to fully reap the gains of international capital inflows, as appreciation pressure will slow down growth as soon as capital inflows allow for an acceleration of the economic catch-up process. "Intermediate regimes” which intervene occasionally against “excessive appreciation” may even face a higher probability of crisis than countries with hard pegs if sustained appreciation expectations encourage additional speculative capital inflows. If capital inflows are curtailed by strict capital controls, domestic interest rates increase and growth will slow down as well

The upshot is that in the absence of a first best solution, in the long run credibly fixed exchange rates are the (second) best solution despite a rising probability of overheating. In this context Ranciere, Tornell and Westermann (2003) argue that although there is a robust positive relationship between the speed of the economic catch-up and crisis, countries which provide favourable conditions for capital inflows - for instance by open capital accounts, macroeconomic and exchange rate stability - grow faster in the long run.

In Japan this effect is called high yen induced recession (endaka fukyo) (McKinnon and Ohno 1997).

Danne and Schnabl (2007) explore the asymmetric impact of the exchange rate on Japanese monetary policy making during the economic catch-up.

8 This hypothesis implies that the respective countries' macroeconomic policies are flexible enough to maintain the peg. If this is not the case, as in Argentina, a flexible exchange rate regime may be the better policy choice. 


\section{Empirical Investigation}

Given the pro and cons about fixed exchange rates in emerging market economies the question about the impact of the exchange rate volatility on growth remains an empirical matter which is scrutinized here for Emerging Europe and East Asia. This investigation builds upon De Grauwe and Schnabl (2005a) for the new EU member states and Schnabl (2006) for the EMU periphery.

\subsection{Sample, Observation Period, and Volatility Measures}

To identify the effect of exchange rate volatility on growth, we specify an unbalanced crosscountry panel model for 17 Emerging European countries and 9 East Asian countries. In addition we use 10 South American countries as a control group (Table 1 provides an overview). First, we include 17 central, eastern and south-eastern European countries which have already joined the European Union or are associated with the EU enlargement process as candidate or potential candidate countries. Serbia and Montenegro are excluded because of insufficient data. Most central, eastern and south-eastern European countries have redirected their exchange rate policies towards the euro.

Second, we include nine East Asian countries, namely China, Hong Kong, Indonesia, Korea, Philippines, Malaysia, Singapore, Taiwan and Thailand. As outlined in section 2 the East Asian emerging economies have pegged their currencies commonly to the dollar (East Asian dollar standard) (McKinnon 2005). The common dollar peg has been regarded as growth enhancing, but we are not aware of any investigation which provides empirical evidence.

The data sources are the IMF International Financial Statistics, the IMF World Economic Outlook and the national central banks. We use yearly data, as for some countries data are only available on a yearly basis. The volatility measures are calculated as yearly averages of monthly percent exchange rate changes. The sample period starts for Emerging Europe in 1994. Because a substantial part of the sample consists of (former) transition economies, the pre-1994 data are unstable and very fragmented. The time period is up to the present (2005).

To test for the impact of exchange rate volatility on economic growth, we use de facto volatility measures, because de jure volatility measures have proved to be flawed by "fear of floating" (Calvo and Reinhart 2002, McKinnon and Schnabl 2004a, De Grauwe and Schnabl 2005a). Exchange rate volatility can be measured in four ways. First, oscillations around a constant level as 
measured by the standard deviation of percent exchange rate changes $(\sigma)$ can be seen as a proxy for uncertainty and transactions costs for international trade and short-term capital flows.

Second, the arithmetic average of percent exchange rate changes $(\mu)$ can be seen as a measure for changes in the exchange rate level, i.e. for "beggar-thy-neighbour" depreciations (positive sign) or a sustained appreciation pressure (negative sign) for the respective economy. Both measures are summarized by the z-score $\left(z_{t}=\sqrt{\mu_{t}^{2}+\sigma_{t}^{2}}\right)$ as proposed by Ghosh, Gulde and Wolf (2003). Fourth, a sustained appreciation or depreciation path can be captured by yearly relative exchange rate changes $(\gamma)$ comparing January with December. Appreciations exhibit a negative sign, depreciations a positive sign.

All four volatility measures are calculated against the euro and the dollar. We compute a minimum measure for exchange rate volatility which includes the smaller volatility either against the euro or the dollar. This is important for the Emerging European countries which have tended to switch their exchange rate targets from the dollar to the euro. For the East Asian countries and the South American countries the volatility measures are only calculated against the dollar.

\subsection{Model Specification and Estimation Procedure}

We use a cross-country panel data model that explains economic growth by exchange rate volatility and a set of control variables: ${ }^{9}$

$w_{i t}=\gamma_{i}+v_{i t}^{\prime} \delta_{i}+\varepsilon_{i t}$,

where $w_{i t}$ is the vector of yearly real growth rates from 1994 to 2005. The explanatory variable $v_{i t}$ consists of the indicators of exchange rate volatility $(\sigma, \mu, \mathrm{z}, \gamma)$ and the control variables.

We use standard deviations of monthly exchange rate changes $(\sigma)$ and January over December percent exchange rate changes $(\gamma)$ as measures for exchange rate volatility. Alternatively, the zscore as a comprehensive measure of both is used. ${ }^{10}$ As discussed in section 2 there are three main transmission channels from exchange rate stability to growth: interest rates, trade and macroeconomic stability. Exchange rate stability is expected to be linked with lower interest rates,

9 See Ghosh, Gulde, and Wolf (2003) and Edwards and Levy-Yeyati (2003) for a similar approach.

10 Yearly percent exchange rate changes are correlated with the means of monthly percent exchange rate changes. 
more trade and lower inflation. We use short-term money market interest rates as a proxy for the interest rate channel. Yearly percent changes of exports in terms of US dollar are used as a proxy for the trade channel. Yearly CPI inflation is used as a proxy for macroeconomic stability.

We include dummies for crisis in emerging markets such as for the 1997/98 Asian crisis, the 1998 Russian crisis and several crises in Latin America (1980-1983, 1994-1995, 1999-2002). The crisis dummies can be seen as a measure for asymmetric shocks. We also include dummies for inflation targeting regimes which are associated with exchange rate flexibility.

There are a large number of other macroeconomic variables which affect growth and therefore may be considered as control variables such as investment, consumption and government spending. Including these variables into the specification increases the fit of the model, but also decreases the degrees of freedom. In addition, in small open economies most macroeconomic variables are influenced by exchange rate volatility as they are strongly dependent on interest rates, trade and inflation. For this reason, we restrict the control variables to the variables described above.

\subsection{Estimation Results}

Both a generalized least square fixed effect (GLS) model as well as a GMM framework are used for the estimations. ${ }^{11}$ The fixed effect specification models the heterogeneity of the countries in the sample. We choose the General Least Squares model as baseline framework, because the concern about endogeneity between growth and the exchange rate regime is low. Within the sample of emerging market economies, fast (slow) growing countries can not be argued to adopt systematically either a fixed or a flexible exchange rate regime. Macroeconomic stability as it is ensured by institutional reforms can be argued to affect both the growth performance and the ability to maintain a fixed exchange rate regime. If the degree of institutional reforms is not included as a control variable this could cause an omitted variable bias. To control for this bias we use inflation as a proxy for institutional reforms.

In addition, there is a concern of endogeneity with respect to the control variables, because trade, interest rates and dollar exports affect growth but are also likely to be affected by the growth performance. To control for this endogeneity bias with respect to the control variables we use a dy-

11 Random effect models lead to by and large the same results. 
namic GMM specification as proposed by Arellano and Bond (1991) and Arellano and Bover (1995). The results from the GLS and GMM specifications remain widely unchanged.

\section{Emerging Europe}

The estimation results for Emerging Europe with respect to exchange rate volatility against the euro provide evidence in favor of a negative correlation between exchange rate volatility and growth. The GLS specification for the whole sample with all control variables provides (rows (1) and (2)) evidence that exchange rate volatility against the euro has a clearly negative impact on growth (Table 2). Both the coefficients for the standard deviations and the z-scores are negative and significant at the 1\%-level. For the yearly change rate the evidence is mixed. Depending on the specification the sign and significance levels change.

The proxies for the transmission channels have the expected signs and are mostly significant at the common levels. Higher interest rates are associated with lower growth at very significant levels. Export growth is positively linked to higher growth, also at very significant levels. Inflation is associated with lower growth, but at lower significance levels. The dummy for inflation targeting has a negative sign and is significant in few specifications suggesting that countries with inflation targeting frameworks may experience lower growth. ${ }^{12}$ For the Emerging European countries which have not experienced a region wide crisis during the observation period ${ }^{13}$, the crisis dummy remains insignificant.

Different specifications (rows (3) to (8)) which exclude one or the other control variable show a stable negative relationship between the z-score and growth. Also the negative sign for the standard deviations is robust. In contrast, without controlling for interest rates, export growth and inflation the coefficient for the yearly exchange rate changes the sign suggesting that appreciation (depreciation) is associated with higher (lower) growth. The GMM specification as reported in Table 3 yields - by and large - unchanged results. The sign of the standard deviations and zscores are in all specifications negative and mostly highly significant indicating a clearly negative impact of exchange rate volatility on growth. The transmission channels have the expected signs and are mostly significant.

12 There are many explanations why this could be the case for the underlying sample but this finding would not be valid in general. One explanation is that inflation targeting frameworks are used as tools for disinflation which lead to negative growth effects in the short-term but would lead to higher long-term growth. Lower growth in countries with inflation targeting regimes would be also in line with findings that inflation targeting is associated with lower output volatility because a lower level of growth is linked to less output volatility. 
An alternative specification estimates the impact of exchange rate volatility on growth for the volatility measure which uses the lowest volatility either against the euro or the dollar (Min) (Table 4 and Table 5). The minimum volatility measure can be regarded as a more precise proxy for exchange rate volatility in the region as some countries in Emerging Europe peg their exchange rates against the dollar or had pegged their exchange rates against the dollar in the early part of our sample period. The estimation results are very similar for the GLS (Table 4) and GMM (Table 5) specification suggesting a robust negative relationship between exchange rate volatility and growth. Inflation targeting frameworks seem to have a negative impact on growth, but remain widely insignificant.

All in all, this suggests that Emerging Europe's move from high exchange rate volatility to increasing exchange rate stability (against the euro) has brought substantial benefits in terms of higher growth. The R-squares suggest that substantial information is drawn from both the time and country dimension of the panel. The benefits arise from lower interest rates, more exports and a higher degree of macroeconomic stability. This confirms the role of interest rates, trade and macroeconomic stability as transmission channels. The anchor currency does not seem to matter for the impact of the exchange rate regime on growth as both exchange rate stabilization against the euro and against the dollar seem to ensure low interest rates (if impediments to international capital flows are removed) and macroeconomic stability.

\section{East Asia}

Before the crisis East Asia has been regarded as a role model for the positive impact of (intraregional) exchange rate stability on (export-led) growth (McKinnon 2005). The observation period for East Asia is considerably longer than for Emerging Europe due to better data availability. The sample starts in 1980 when most countries in the sample had adopted export-oriented industrialization strategies. Exchange rate volatility is calculated against the dollar. Note that for the East Asian sample the fit of the model is substantially larger than for the Emerging Europe sample.

For the whole sample period the negative impact of exchange rate volatility on growth is strongly confirmed for both the GLS specification (Table 6). The coefficients of exchange rate volatility

3 Some countries were affected by crisis at different points of time such as Estonia by the Russian crisis in 1998 and the Czech Republic in 1997. 
measured in terms of standard deviations and z-scores are negative and highly significant suggesting a strong negative impact of exchange rate volatility on growth. Also the coefficient measuring appreciation (depreciation) of the East Asian currencies has the expected sign and is highly significant. Appreciation (depreciation) is strongly associated with less (more) growth. This may explain the strong inclination of the East Asian countries to stabilize exchange rates against the dollar (Dooley, Folkerts-Landau and Garber 2003).

The results for the controls variables have mostly the expected signs. Like for Emerging Europe, the specification with all control variables has the best fit. Exports have a strongly positive impact on growth. Macroeconomic instability (higher inflation) is associated with lower growth. In contrast to Emerging Europe the interest rate has not the expected sign and is insignificant. The dummy for the 1997/98 Asian crisis which controls for the negative impact of the volatility associated with the crisis is clearly negative and highly significant. This reflects the fact that the East Asian crisis was much more severe in East Asia than the instabilities during the observation period in Emerging Europe which tended to effect only single countries but not the whole country group.

In line with Emerging Europe the dummy for inflation targeting frameworks is mostly negative, associating inflation targeting with lower growth. In contrast to Emerging Europe the coefficients remain widely insignificant. This may be due to two reasons. First, the impact of inflation targeting on growth is weak. Second, the East Asian countries have widely exhibited "fear of floating" even after they have adopted inflation targeting frameworks (Calvo and Reinhart 2002).

\subsection{Sensitivity Analysis}

The GMM estimation for the East Asian sample is not robust and therefore not reported here. To increase the sample size of the East Asian sample we add 10 South American countries to increase the sample size (for composition of the country group see Table 1). In contrast to East Asia, the South American countries can be seen as a country group where macroeconomic and exchange rate instability prevailed during most of the observation period. The observation period for this pooled sample is from 1980 to 2005 for the GLS specification and from 1986 to 2005 for the GMM specification, because the GMM results are not stable for the 1980 to 2005 observation period. Both the GLS (Table 7) and GMM (Table 8) estimations confirm the results for the single country groups. 
The coefficients for the standard deviations and z-scores are clearly negative and mostly highly significant for both estimation frameworks. Also the yearly exchange rate changes have (the expected) positive sign at highly significant levels. This implies a clearly negative impact of exchange rate volatility on growth for the pooled East Asian and South American sample. The role of the export growth and macroeconomic stability (inflation) as transmission channels is confirmed, while the results for interest rates remain mixed.

A second set of robustness tests finally pools East Asia and Emerging Europe. As the Emerging European sample only starts in 1994, the observation period is restricted to 1994 to 2005. The results are reported in Table 9 (GLS) and Table 10 (GMM). Both the Emerging European and the East Asian sample provide evidence that exchange rate volatility is detrimental for growth. The control variables confirm the important role of international trade and macroeconomic stability as transmission channels from exchange rate stability to growth. For the interest rate channel the evidence is mixed.

We pool Emerging Europe and East Asian to provide a comprehensive picture for the interdependence of exchange rate volatility and growth in emerging market economies. The pooled sample allows for more heterogeneity within the sample. We restrict the pooled sample to the period from 1994 to 2005 as data are not available for Emerging Europe prior to the year 1994. The results are shown in Table 9 (GLS) and Table 10 (GMM). There is strong evidence that exchange rate volatility affects growth negatively if exchange rate volatility is measured in terms of standard deviations and z-scores.

All in all, the negative impact of exchange rate volatility for economic growth seems to be robust suggesting that stable exchange rates are the better strategy for emerging market economies with underdeveloped capital markets and open capital accounts. The role of international trade, interest rates and macroeconomic stability as transmission channels is confirmed.

\section{Conclusion}

We have tested for the impact of exchange rate volatility on economic growth in Emerging Europe and East Asia which are country groups which have widely dismantled capital controls in the observation periods. While East Asia has traditionally maintained a high degree of exchange rate stability it has moved towards (slightly) more exchange rate volatility (against the dollar). Emerging Europe has continued to pursue increasingly exchange rate stability against the euro 
although some countries such as Poland and the Czech Republic have allowed their currencies to float substantially.

We have shown that there is no straightforward theoretical evidence in favour of or against exchange rate stability in emerging market economies. Nevertheless, our empirical investigations suggest that emerging markets with fixed exchange rates grow faster. The reason is that fixed exchange rates have a positive impact on international trade, interest rates and macroeconomic stability. As a pre-requisite capital controls have to be dismantled to allow for arbitrage in international goods and capital markets. Note that open capital accounts in combination with fixed exchange rates require macroeconomic stability and flexibility which are ensured by institutional reforms and therefore invite growth enhancing international capital flows.

Despite the strong evidence in favour of a positive impact of exchange rate stability on growth the relationship between exchange rate stability and growth is not a linear one as discussed in section 2.4. Favourable conditions for international investment may encourage speculative capital inflows and overheating as experienced in the case of the Asian crisis. This does not imply, however, that countries should per se adopt flexible exchange rate regimes to reduce the likelihood of crisis because the price would be a considerable lower level of growth due to increasing macroeconomic instability under flexible exchange rate regimes. A systematic analysis of the interdependence between stable exchange rates, macroeconomic stability and institutional reforms remains subject to further research. 


\section{References}

Aghion, Philippe / Bachetta, Philippe / Ranciere, Romain / Rogoff, Kenneth 2005: Productivity Growth and the Exchange Rate Regime: the Role of Financial Development. NBER Working Paper 12117.

Arellano, Manuel / Bond, Stephen 1991: Some Tests of Specification for Panel Data: Monte Carlo Evidence and an Application to Employment Equations. Review of Economic Studies 58, 277-297.

Arellano, Manuel / Bover, Olympia 1995: Another Look at the Instrumental-Variable Estimation of Error-Components Models. Journal of Econometrics 68, 29-51.

Bachetta, Philippe / van Wincoop, Eric 2000: Does Exchange Rate Stability Increase Trade and Welfare? American Economic Review 90, 1093-1109.

Backé, Peter / Egert, Balasz / Zumer, Tina 2006: Credit Growth in Central and Eastern Europe. ECB Working Paper 687.

Calvo, Guillermo / Reinhart, Carmen 2002: Fear of Floating. Quarterly Journal of Economics 117, 2, 379-408.

Danne, Christian / Schnabl, Gunther 2007: A Role Model for China? Exchange Rate Flexibility and Monetary Policy in Japan. Mimeo.

De Grauwe, Paul / Schnabl, Gunther 2005a: Exchange Rate Regime and Macroeconomic Performance in Central and Eastern Europe. CESifo Working Paper 1182.

De Grauwe, Paul and Gunther Schnabl 2005b: Nominal versus Real Convergence with Respect to EMU Accession - EMU Entry Scenarios for the New Member States. Kyklos 58, 4, 481-499.

Dooley, Michael, David Folkerts-Landau, and Peter Garber 2003: An Essay on the Revived Bretton Woods System. NBER Working Paper 9971.

Dornbusch, Rüdiger 2001: Fewer Monies Better Monies, Discussion on Exchange Rates and the Choice of Monetary-Policy Regimes. American Economic Review 91, 238-242.

Edwards, Sebastian / Levy-Yeyati, Eduardo 2003: Flexible Exchange Rates as Shock Absorbers, NBER Working Paper 9867.

Eichengreen, Barry / Hausmann, Ricardo 1999: Exchange Rates and Financial Fragility. NBER Working Paper 7418.

Eichengreen, Barry / Leblang, David 2003: Exchange Rates and Cohesion: Historical Perspectives and Political-Economy Considerations. Journal of Common Market Studies 41, 797-822.

European Central Bank (ECB) 2005: Review of the International Role of the Euro, Frankfurt.

European Commission 1990: One Market, One Money: An Evaluation of the Potential Benefits and Costs of Forming an Economic and Monetary Union. European Economy 44.

Fidrmuc, Jarko / Korhonen, Iikka 2006: Meta-Analysis of the Business Cycle Correlation between the Euro Area and the CEECs. Journal of Comparative Economics 34.

Fischer, Stanley 2001: Exchange Rate Regimes: Is the Bipolar View Correct? Journal of Economic Perspectives 15, 2, 3-24.

Frankel, Jeffrey / Rose, Andrew 2002: An Estimate of the Effect of Common Currencies on Trade and Income. Quarterly Journal of Economics 117, 437-66.

Friedman, Milton 1953: The Case for Flexible Exchange Rates. In Essays of Positive Economics, ed. by Milton Friedman (Chicago: University of Chicago Press).

Ghosh, Atish / Gulde, Anne-Marie / Wolf, Holger 2003: Exchange Rate Regimes: Choices and Consequences (Cambridge, Massachusetts: MIT Press).

International Monetary Fund 1984: Exchange Rate Variability and World Trade, IMF Occasional Paper 28 (Washington: International Monetary Fund).

Kamps, Annette 2006: The Euro as Invoicing Currency in International Trade. European Central Bank Working Paper 665.

Krugman, Paul 1979: A Model of Balance of Payments Crisis. Journal of Money, Credit and Banking 11, 311-325. 
Martin, Rainer / Schuknecht, Ludger / Vansteenkiste, Isabell 2007: Boom and Bust Episodes and the Choice of Adjustment Strategy. Mimeo.

McKinnon, Ronald 1963: Optimum Currency Areas. American Economic Review 53, 717-25.

McKinnon, Ronald 1973: Money and Capital in Economic Development. Brookings Institution.

McKinnon, Ronald 2005: Exchange Rates under the East Asian Dollar Standard: Living with Conflicted Virtue. Cambridge, Massachusetts.

McKinnon, Ronald / Ohno, Kenichi 1997: Dollar and Yen. Resolving Economic Conflict between the United States and Japan. Cambridge, Massachusetts.

McKinnon, Ronald / Schnabl, Gunther 2003: Synchronized Business Cycles in East Asia and Fluctuations in the Yen/Dollar Exchange Rate. The World Economy 26, 8, 1067-1088.

McKinnon, Ronald and Gunther Schnabl 2004a: The East Asian Dollar Standard, Fear of Floating, and Original Sin. Review of Development Economics 8, 3, 331-60.

McKinnon, Ronald and Gunther Schnabl 2004b: A Return to Soft Dollar Pegging in East Asia? Mitigating Conflicted Virtue. International Finance 7, 2, 169-201.

Meade, James 1951: The Theory of International Economic Policy (London: Oxford University Press).

Micco, Alejandro / Stein, Ernesto / Ordoñez, Guillermo 2003: The Currency Union Effect on Trade: Early Evidence from EMU. Economic Policy 18, 37, 315-56.

Mundell, Robert 1961: A Theory of Optimal Currency Areas. American Economic Review 51, 4, 657-65.

Mundell, Robert 1973a: A Plan for a European Currency. In The Economics of Common Currencies, ed. by Harry Johnson and Alexander Swoboda (London: Allen and Unwin).

Mundell, Robert 1973b: Uncommon Arguments for Common Currencies. In The Economics of Common Currencies, ed. by Harry Johnson and Alexander Swoboda (London: Allen and Unwin).

Ranciere, Romain / Tornell, Aaron / Westermann, Frank 2005: Crisis and Growth: a REEvaluation. NBER Working Paper 10073.

Schnabl, Gunther 2006: Exchange Rate Volatility and Growth in Small Open Economies at the EMU Periphery. Mimeo.

World Bank 1993: The East Asian Miracle: Economic Growth and Public Policy, Oxford University Press. 


\begin{tabular}{|c|c|c|c|}
\hline & Countries & IFS County Code & Panel ID \\
\hline \multirow[t]{17}{*}{ Emerging Europe } & Bulgaria & 918 & 1 \\
\hline & Croatia & 960 & 2 \\
\hline & Romania & 968 & 3 \\
\hline & Turkey & 186 & 4 \\
\hline & Albania & 914 & 5 \\
\hline & Bosnia-Herzegovina & 963 & 6 \\
\hline & FYR Macedonia & 962 & 7 \\
\hline & Cyprus & 423 & 8 \\
\hline & Czech Republic & 935 & 9 \\
\hline & Hungary & 944 & 10 \\
\hline & Latvia & 941 & 11 \\
\hline & Lithuania & 946 & 12 \\
\hline & Estonia & 939 & 13 \\
\hline & Malta & 181 & 14 \\
\hline & Poland & 964 & 15 \\
\hline & Slovak Republic & 936 & 16 \\
\hline & Slovenia & 961 & 17 \\
\hline \multirow[t]{9}{*}{ East Asia } & China & 924 & 18 \\
\hline & Hongkong & 532 & 19 \\
\hline & Indonesia & 536 & 20 \\
\hline & Korea & 542 & 21 \\
\hline & Malaysia & 548 & 22 \\
\hline & Philippines & 566 & 23 \\
\hline & Singapore & 576 & 24 \\
\hline & Taiwan & 528 & 25 \\
\hline & Thailand & 578 & 26 \\
\hline \multirow[t]{10}{*}{ Latin America } & Argentina & 213 & 27 \\
\hline & Bolivia & 218 & 28 \\
\hline & Brazil & 223 & 29 \\
\hline & Chile & 228 & 30 \\
\hline & Colombia & 233 & 31 \\
\hline & Ecuador & 248 & 32 \\
\hline & Paraguay & 288 & 33 \\
\hline & Peru & 293 & 34 \\
\hline & Uruguay & 298 & 35 \\
\hline & Venezuela & 299 & 36 \\
\hline
\end{tabular}

Note: Serbia and Montenegro were removed due to insufficient data. 
Table 2: GLS Estimation Results for the Emerging Europe 1994 - 2005 (Euro)

\begin{tabular}{|c|c|c|c|c|c|c|c|c|}
\hline & (1) & (2) & (3) & (4) & (5) & (6) & (7) & (8) \\
\hline Standard deviation & $\begin{array}{c}-0.587 * * * \\
(0.159)\end{array}$ & & $\begin{array}{c}-0.693 * * * \\
(0.130)\end{array}$ & & $\begin{array}{c}-0.525 * * * \\
(0.160)\end{array}$ & & $\begin{array}{l}-0.102 \\
(0.063)\end{array}$ & \\
\hline Yearly change & $\begin{array}{c}-0.004 \\
(0.009)\end{array}$ & & $\begin{array}{c}0.006 \\
(0.008)\end{array}$ & & $\begin{array}{c}-0.019 * * * \\
(0.007)\end{array}$ & & $\begin{array}{c}-0.029 * * * \\
(0.007)\end{array}$ & \\
\hline Z-score & & $\begin{array}{c}-0.545 * * * \\
(0.121)\end{array}$ & & $\begin{array}{c}-0.606 * * * \\
(0.116)\end{array}$ & & $\begin{array}{c}-0.731 * * * \\
(0.107)\end{array}$ & & $\begin{array}{c}-0.252 * * * \\
(0.048)\end{array}$ \\
\hline Interest rate & $\begin{array}{c}-0.067 * * * \\
(0.022)\end{array}$ & $\begin{array}{c}-0.053 * * * \\
(0.017)\end{array}$ & $\begin{array}{c}-0.083 * * * \\
(0.018)\end{array}$ & $\begin{array}{c}-0.063 * * * \\
(0.016)\end{array}$ & & & & \\
\hline Export growth & $\begin{array}{c}0.057 * * * \\
(0.013)\end{array}$ & $\begin{array}{c}0.059 * * * \\
(0.012)\end{array}$ & $\begin{array}{c}0.045^{* * *} \\
(0.009)\end{array}$ & $\begin{array}{c}0.042 * * * \\
(0.009)\end{array}$ & $\begin{array}{c}0.074^{* * *} \\
(0.010)\end{array}$ & $\begin{array}{c}0.077 * * * \\
(0.009)\end{array}$ & & \\
\hline Inflation & $\begin{array}{l}-0.015 \\
(0.012)\end{array}$ & $\begin{array}{c}-0.019 * * \\
(0.009)\end{array}$ & & & $\begin{array}{c}-0.033 * * * \\
(0.009)\end{array}$ & $\begin{array}{c}-0.025^{* * *} \\
(0.009)\end{array}$ & & \\
\hline Inflation target & $\begin{array}{l}-0.013 \\
(0.008)\end{array}$ & $\begin{array}{l}-0.013 \\
(0.008)\end{array}$ & $\begin{array}{l}-0.014^{*} \\
(0.008)\end{array}$ & $\begin{array}{c}-0.014 \\
(0.008)\end{array}$ & $\begin{array}{c}-0.008 \\
(0.008)\end{array}$ & $\begin{array}{c}-0.006 \\
(0.008)\end{array}$ & $\begin{array}{l}-0.013 \\
(0.009)\end{array}$ & $\begin{array}{l}-0.011 \\
(0.009)\end{array}$ \\
\hline Crisis & $\begin{array}{c}0.000 \\
(0.004)\end{array}$ & $\begin{array}{l}-0.000 \\
(0.004)\end{array}$ & $\begin{array}{l}-0.000 \\
(0.004)\end{array}$ & $\begin{array}{l}-0.001 \\
(0.004)\end{array}$ & $\begin{array}{l}-0.001 \\
(0.004)\end{array}$ & $\begin{array}{l}-0.002 \\
(0.004)\end{array}$ & $\begin{array}{l}-0.004 \\
(0.005)\end{array}$ & $\begin{array}{l}-0.004 \\
(0.005)\end{array}$ \\
\hline Constant & $\begin{array}{c}0.054 * * * \\
(0.004)\end{array}$ & $\begin{array}{c}0.053 * * * \\
(0.004)\end{array}$ & $\begin{array}{c}0.057 * * * \\
(0.004)\end{array}$ & $\begin{array}{c}0.055^{* * * *} \\
(0.003)\end{array}$ & $\begin{array}{c}0.045^{* * * *} \\
(0.003)\end{array}$ & $\begin{array}{c}0.046^{* * * *} \\
(0.003)\end{array}$ & $\begin{array}{c}0.048 * * * \\
(0.003)\end{array}$ & $\begin{array}{c}0.048 * * * \\
(0.003)\end{array}$ \\
\hline Observations & 180 & 180 & 184 & 184 & 192 & 192 & 200 & 200 \\
\hline Number of id & 16 & 16 & 17 & 17 & 16 & 16 & 17 & 17 \\
\hline $\mathrm{R}^{2}$ within & 0.438 & 0.438 & 0.429 & 0.421 & 0.392 & 0.393 & 0.197 & 0.142 \\
\hline $\mathrm{R}^{2}$ between & 0.296 & 0.292 & 0.329 & 0.333 & 0.184 & 0.129 & 0.324 & 0.318 \\
\hline $\mathrm{R}^{2}$ overall & 0.342 & 0.340 & 0.332 & 0.333 & 0.336 & 0.313 & 0.216 & 0.164 \\
\hline
\end{tabular}

Data source: IMF, national central banks. *Significant at the $10 \%$ level. $* *$ Significant at the $5 \%$ level. ***Significant at the $1 \%$ level. 
Table 3: GMM - Two Step Estimation Results for Emerging Europe 1994 - 2005 (Euro)

\begin{tabular}{|c|c|c|c|c|c|c|c|c|}
\hline & (1) & (2) & (3) & (4) & (5) & (6) & (7) & (8) \\
\hline Growth & $\begin{array}{c}-0.143 \\
(0.174)\end{array}$ & $\begin{array}{c}-0.119 \\
(0.160)\end{array}$ & $\begin{array}{c}0.008 \\
(0.096)\end{array}$ & $\begin{array}{c}-0.065 \\
(0.046)\end{array}$ & $\begin{array}{c}0.046 \\
(0.054)\end{array}$ & $\begin{array}{c}0.129 \\
(0.113)\end{array}$ & $\begin{array}{c}0.209 * * * \\
(0.074)\end{array}$ & $\begin{array}{c}0.148 * * * \\
(0.029)\end{array}$ \\
\hline Standard deviation & $\begin{array}{c}-0.308 \\
(0.387)\end{array}$ & & $\begin{array}{c}-1.153 * * * \\
(0.229)\end{array}$ & & $\begin{array}{c}-0.334 \\
(0.223)\end{array}$ & & $\begin{array}{c}-0.091 * * * \\
(0.018)\end{array}$ & \\
\hline Yearly change & $\begin{array}{c}-0.003 \\
(0.020)\end{array}$ & & $\begin{array}{c}0.037 * * * \\
(0.012)\end{array}$ & & $\begin{array}{c}-0.019 * * * \\
(0.005)\end{array}$ & & $\begin{array}{c}-0.022 * * * \\
(0.004)\end{array}$ & \\
\hline Z-score & & $\begin{array}{c}-0.285 \\
(0.349)\end{array}$ & & $\begin{array}{c}-0.747 * * * \\
(0.041)\end{array}$ & & $\begin{array}{c}-0.918 * * * \\
(0.212)\end{array}$ & & $\begin{array}{c}-0.115 * * * \\
(0.039)\end{array}$ \\
\hline Interest rate & $\begin{array}{c}-0.061 \\
(0.061)\end{array}$ & $\begin{array}{c}-0.084 * \\
(0.048)\end{array}$ & $\begin{array}{c}-0.193 * * * \\
(0.048)\end{array}$ & $\begin{array}{c}-0.073 * * * \\
(0.022)\end{array}$ & & & & \\
\hline Export growth & $\begin{array}{c}0.051 * * \\
(0.021)\end{array}$ & $\begin{array}{c}0.079 * * * \\
(0.019)\end{array}$ & $\begin{array}{c}0.076 * * * \\
(0.015)\end{array}$ & $\begin{array}{c}0.053 * * * \\
(0.004)\end{array}$ & $\begin{array}{c}0.074 * * * \\
(0.025)\end{array}$ & $\begin{array}{c}0.069 * * * \\
(0.024)\end{array}$ & & \\
\hline Inflation & $\begin{array}{c}-0.028 \\
(0.024)\end{array}$ & $\begin{array}{c}-0.052 * * \\
(0.022)\end{array}$ & & & $\begin{array}{c}-0.043^{* *} \\
(0.020)\end{array}$ & $\begin{array}{l}-0.006 \\
(0.011)\end{array}$ & & \\
\hline Inflation target & $\begin{array}{c}-0.007 \\
(0.009)\end{array}$ & $\begin{array}{l}-0.009 \\
(0.007)\end{array}$ & $\begin{array}{c}0.000 \\
(0.009)\end{array}$ & $\begin{array}{c}-0.007 \\
(0.006)\end{array}$ & $\begin{array}{l}-0.002 \\
(0.006)\end{array}$ & $\begin{array}{c}0.002 \\
(0.008)\end{array}$ & $\begin{array}{c}-0.006 \\
(0.007)\end{array}$ & $\begin{array}{c}-0.013^{* *} \\
(0.006)\end{array}$ \\
\hline Crisis & $\begin{array}{c}0.003 \\
(0.003)\end{array}$ & $\begin{array}{c}-0.001 \\
(0.003)\end{array}$ & $\begin{array}{c}-0.003 \\
(0.003)\end{array}$ & $\begin{array}{l}-0.001 \\
(0.002)\end{array}$ & $\begin{array}{c}0.002 \\
(0.004)\end{array}$ & $\begin{array}{c}0.002 \\
(0.004)\end{array}$ & $\begin{array}{c}0.001 \\
(0.001)\end{array}$ & $\begin{array}{c}0.002 \\
(0.002)\end{array}$ \\
\hline Constant & $\begin{array}{c}0.000 \\
(0.001)\end{array}$ & $\begin{array}{c}-0.001 \\
(0.001)\end{array}$ & $\begin{array}{c}-0.003 * * * \\
(0.001)\end{array}$ & $\begin{array}{c}-0.001 \\
(0.001)\end{array}$ & $\begin{array}{c}-0.000 \\
(0.001)\end{array}$ & $\begin{array}{c}-0.001 \\
(0.001)\end{array}$ & $\begin{array}{l}-0.000 \\
(0.001)\end{array}$ & $\begin{array}{c}0.001 \\
(0.001)\end{array}$ \\
\hline Observations & 151 & 153 & 153 & 153 & 160 & 160 & 167 & 167 \\
\hline Number of id & 16 & 17 & 17 & 17 & 16 & 16 & 17 & 17 \\
\hline Sargan test Chi ${ }^{2}$ & 6.62 & 8.11 & 12.44 & 10.48 & 6.31 & 7.49 & 13.53 & 14.93 \\
\hline Prob $>\mathrm{Chi}^{2}$ & 1.000 & 1.000 & 1.000 & 1.000 & 1.000 & 1.000 & 1.000 & 1.000 \\
\hline $\operatorname{AR}(2)$ & 0.993 & 0.733 & 0.635 & 0.929 & 0.320 & 0.339 & 0.459 & 0.568 \\
\hline
\end{tabular}

Data source: IMF, national central banks. *Significant at the $10 \%$ level. **Significant at the $5 \%$ level. ***Significant at the $1 \%$ level. 
Table 4: GLS Estimation Results for the Emerging Europe 1994 - 2005 (Min)

\begin{tabular}{|c|c|c|c|c|c|c|c|c|}
\hline & (1) & (2) & (3) & (4) & (5) & (6) & (7) & (8) \\
\hline \multirow[t]{2}{*}{ Standard deviation } & $-0.597 * * *$ & & $-0.697 * * *$ & & $-0.493 * * *$ & & $-0.103^{*}$ & \\
\hline & $(0.160)$ & & (0.129) & & (0.161) & & $(0.063)$ & \\
\hline \multirow[t]{2}{*}{ Yearly change } & 0.001 & & 0.006 & & $-0.019 * * *$ & & $-0.029 * * *$ & \\
\hline & $(0.009)$ & & $(0.008)$ & & $(0.007)$ & & $(0.007)$ & \\
\hline \multirow[t]{2}{*}{ Z-score } & & $-0.512 * * *$ & & $-0.582 * * *$ & & $-0.702 * * *$ & & $-0.249 * * *$ \\
\hline & & (0.119) & & $(0.114)$ & & (0.108) & & $(0.048)$ \\
\hline \multirow[t]{2}{*}{ Interest rate } & $-0.069 * * *$ & $-0.057 * * *$ & $-0.082 * * *$ & $-0.065 * * *$ & & & & \\
\hline & $(0.021)$ & $(0.017)$ & $(0.017)$ & $(0.016)$ & & & & \\
\hline \multirow{2}{*}{ Export growth } & $0.054 * * *$ & $0.056 * * *$ & $0.045 * * *$ & $0.041 * * *$ & $0.071 * * *$ & $0.073 * * *$ & & \\
\hline & $(0.012)$ & $(0.009)$ & $(0.009)$ & $(0.009)$ & $(0.010)$ & (0.009) & & \\
\hline \multirow[t]{2}{*}{ Inflation } & -0.013 & $-0.018 *$ & & & $-0.033 * * *$ & $-0.024^{* * *}$ & & \\
\hline & $(0.012)$ & $(0.010)$ & & & (0.009) & (0.009) & & \\
\hline \multirow[t]{2}{*}{ Inflation target } & -0.013 & -0.013 & -0.013 & -0.013 & -0.008 & -0.006 & -0.013 & -0.010 \\
\hline & $(0.008)$ & $(0.008)$ & $(0.008)$ & $(0.008)$ & $(0.009)$ & $(0.008)$ & $(0.009)$ & $(0.009)$ \\
\hline \multirow[t]{2}{*}{ Crisis } & -0.001 & -0.002 & -0.001 & -0.002 & -0.003 & -0.003 & -0.005 & -0.005 \\
\hline & $(0.004)$ & $(0.004)$ & $(0.004)$ & $(0.004)$ & $(0.004)$ & $(0.004)$ & $(0.005)$ & $(0.005)$ \\
\hline \multirow[t]{2}{*}{ Constant } & $0.053 * * *$ & $0.052 * * *$ & $0.055 * * *$ & $0.054 * * *$ & $0.044 * * *$ & $0.045 * * *$ & $0.047 * * *$ & $0.047 * * *$ \\
\hline & $(0.004)$ & $(0.004)$ & $(0.004)$ & $(0.004)$ & $(0.003)$ & $(0.003)$ & $(0.003)$ & $(0.003)$ \\
\hline Observations & 184 & 184 & 184 & 184 & 197 & 197 & 200 & 200 \\
\hline Number of id & 17 & 17 & 17 & 17 & 17 & 17 & 17 & 17 \\
\hline $\mathrm{R}^{2}$ within & 0.435 & 0.428 & 0.432 & 0.416 & 0.383 & 0.376 & 0.194 & 0.139 \\
\hline $\mathrm{R}^{2}$ between & 0.355 & 0.359 & 0.333 & 0.343 & 0.271 & 0.211 & 0.333 & 0.325 \\
\hline $\mathrm{R}^{2}$ overall & 0.354 & 0.346 & 0.344 & 0.337 & 0.345 & 0.318 & 0.214 & 0.163 \\
\hline
\end{tabular}

Data source: IMF, national central banks. *Significant at the $10 \%$ level. **Significant at the $5 \%$ level. ***Significant at the $1 \%$ level. 
Table 5: GMM - Two Step Estimation Results for Emerging Europe 1994 - 2005 (Min)

\begin{tabular}{|c|c|c|c|c|c|c|c|c|}
\hline & (1) & (2) & (3) & (4) & (5) & (6) & (7) & (8) \\
\hline Growth & $\begin{array}{l}-0.114 \\
(0.15)\end{array}$ & $\begin{array}{c}0.049 \\
(0.015)\end{array}$ & $\begin{array}{c}-0.025 \\
(0.096) \\
\end{array}$ & $\begin{array}{c}0.038 \\
(0.080)\end{array}$ & $\begin{array}{c}-0.048 \\
(0.226)\end{array}$ & $\begin{array}{l}0.254^{*} \\
(0.149)\end{array}$ & $\begin{array}{c}0.227 * * * \\
(0.076)\end{array}$ & $\begin{array}{c}0.152 * * * \\
(0.041)\end{array}$ \\
\hline Standard deviation & $\begin{array}{l}-0.407 \\
(0.649)\end{array}$ & & $\begin{array}{c}-0.903^{* * *} \\
(0.116)\end{array}$ & & $\begin{array}{l}-0.019 \\
(0.639)\end{array}$ & & $\begin{array}{c}-0.091 * * * \\
(0.017)\end{array}$ & \\
\hline Yearly change & $\begin{array}{c}0.004 \\
(0.030)\end{array}$ & & $\begin{array}{c}0.033^{* * *} * \\
(0.010)\end{array}$ & & $\begin{array}{l}-0.029 * \\
(0.011)\end{array}$ & & $\begin{array}{c}-0.023^{* * * *} \\
(0.005)\end{array}$ & \\
\hline Z-score & & $\begin{array}{c}-0.373 \\
(0.274)\end{array}$ & & $\begin{array}{c}-0.605 * * * \\
(0.017)\end{array}$ & & $\begin{array}{c}-1.059 * * * \\
(0.365)\end{array}$ & & $\begin{array}{c}-0.141^{* * *} \\
(0.025)\end{array}$ \\
\hline Interest rate & $\begin{array}{c}-0.084 \\
(0.071)\end{array}$ & $\begin{array}{c}-0.098 * * * \\
(0.037)\end{array}$ & $\begin{array}{c}-0.189 * * * \\
(0.039)\end{array}$ & $\begin{array}{c}-0.106^{* * *} \\
(0.027)\end{array}$ & & & & \\
\hline Export growth & $\begin{array}{c}0.046^{* * *} \\
(0.016)\end{array}$ & $\begin{array}{c}0.088 * * * \\
(0.021)\end{array}$ & $\begin{array}{c}0.059 * * * \\
(0.007)\end{array}$ & $\begin{array}{c}0.045^{* * * *} \\
(0.009)\end{array}$ & $\begin{array}{c}0.089 * * * \\
(0.018)\end{array}$ & $\begin{array}{c}0.083^{* * *} * \\
(0.016)\end{array}$ & & \\
\hline Inflation & $\begin{array}{l}-0.019 \\
(0.036)\end{array}$ & $\begin{array}{c}-0.052^{* * *} \\
(0.017)\end{array}$ & & & $\begin{array}{c}-0.075^{* *} \\
(0.039)\end{array}$ & $\begin{array}{l}-0.007 \\
(0.021)\end{array}$ & & \\
\hline Inflation target & $\begin{array}{l}-0.006 \\
(0.009)\end{array}$ & $\begin{array}{l}-0.003 \\
(0.006)\end{array}$ & $\begin{array}{c}0.000 \\
(0.008)\end{array}$ & $\begin{array}{c}-0.003 \\
(0.006)\end{array}$ & $\begin{array}{c}-0.002 \\
(0.007)\end{array}$ & $\begin{array}{c}0.004 \\
(0.007)\end{array}$ & $\begin{array}{l}-0.005 \\
(0.007)\end{array}$ & $\begin{array}{c}-0.011 * \\
(0.007)\end{array}$ \\
\hline Crisis & $\begin{array}{c}0.000 \\
(0.000)\end{array}$ & $\begin{array}{l}-0.001 \\
(0.002)\end{array}$ & $\begin{array}{c}-0.003 \\
(0.003)\end{array}$ & $\begin{array}{l}-0.001 \\
(0.003)\end{array}$ & $\begin{array}{l}-0.001 \\
(0.003)\end{array}$ & $\begin{array}{l}-0.005 \\
(0.003)\end{array}$ & $\begin{array}{c}0.001 \\
(0.001)\end{array}$ & $\begin{array}{c}0.001 \\
(0.002)\end{array}$ \\
\hline Constant & $\begin{array}{c}0.000 \\
(0.000)\end{array}$ & $\begin{array}{c}-0.002 \\
(0.001)\end{array}$ & $\begin{array}{l}-0.002^{*} \\
(0.001)\end{array}$ & $\begin{array}{c}-0.002 \\
(0.001)\end{array}$ & $\begin{array}{l}-0.000 \\
(0.001)\end{array}$ & $\begin{array}{l}-0.001 \\
(0.001)\end{array}$ & $\begin{array}{l}-0.000 \\
(0.001)\end{array}$ & $\begin{array}{c}0.000 \\
(0.000)\end{array}$ \\
\hline Observations & 153 & 153 & 153 & 153 & 164 & 164 & 167 & 167 \\
\hline Number of id & 17 & 17 & 17 & 17 & 17 & 17 & 17 & 17 \\
\hline Sargan test Chi $^{2}$ & 8.66 & 10.23 & 13.82 & 13.71 & 10.07 & 11.08 & 13.26 & 15.49 \\
\hline Prob $>\mathrm{Chi}^{2}$ & 1.000 & 1.000 & 1.000 & 1.000 & 1.000 & 1.000 & 1.000 & 1.000 \\
\hline $\operatorname{AR}(2)$ & 0.931 & 0.248 & 0.558 & 0.448 & 0.597 & 0.229 & 0.471 & 0.554 \\
\hline
\end{tabular}


Table 6: GLS Estimation Results for East Asia 1980 - 2005 (Dollar)

\begin{tabular}{|c|c|c|c|c|c|c|c|c|}
\hline & (1) & (2) & (3) & (4) & (5) & (6) & (7) & (8) \\
\hline Standard deviation & $\begin{array}{c}-0.627 * * * \\
(0.116)\end{array}$ & & $\begin{array}{c}-0.687 * * * \\
(0.115)\end{array}$ & & $\begin{array}{c}-0.547 * * * \\
(0.109)\end{array}$ & & $\begin{array}{c}-0.654 * * * \\
(0.106)\end{array}$ & \\
\hline Yearly change & $\begin{array}{c}0.071 * * * \\
(0.017)\end{array}$ & & $\begin{array}{c}0.080 * * * \\
(0.017)\end{array}$ & & $\begin{array}{c}0.071 * * * \\
(0.017)\end{array}$ & & $\begin{array}{c}0.061^{* * *} \\
(0.020)\end{array}$ & \\
\hline Z-score & & $\begin{array}{c}-0.323 * * * \\
(0.098)\end{array}$ & & $\begin{array}{c}-0.338 * * * \\
(0.099)\end{array}$ & & $\begin{array}{c}-0.257 * * * \\
(0.091)\end{array}$ & & $\begin{array}{c}-0.425 * * * \\
(0.088)\end{array}$ \\
\hline Interest rate & $\begin{array}{c}0.126^{*} \\
(0.074)\end{array}$ & $\begin{array}{c}0.099 \\
(0.076)\end{array}$ & $\begin{array}{c}0.046 \\
(0.059)\end{array}$ & $\begin{array}{c}-0.028 \\
(0.062)\end{array}$ & & & & \\
\hline Export growth & $\begin{array}{c}0.154^{* * * *} \\
(0.016)\end{array}$ & $\begin{array}{c}0.152^{* * * *} \\
(0.017)\end{array}$ & $\begin{array}{c}0.145^{* * *} \\
(0.016)\end{array}$ & $\begin{array}{c}0.141^{* * * *} \\
(0.017)\end{array}$ & $\begin{array}{c}0.158 * * * \\
(0.016)\end{array}$ & $\begin{array}{c}0.155^{* * *} \\
(0.017)\end{array}$ & & \\
\hline Inflation & $\begin{array}{c}-0.091 * \\
(0.049)\end{array}$ & $\begin{array}{c}-0.124 * * \\
(0.051)\end{array}$ & & & $\begin{array}{l}-0.038 \\
(0.039)\end{array}$ & $\begin{array}{c}-0.082 * * \\
(0.040)\end{array}$ & & \\
\hline Inflation target & $\begin{array}{c}0.003 \\
(0.008)\end{array}$ & $\begin{array}{l}-0.007 \\
(0.008)\end{array}$ & $\begin{array}{c}0.001 \\
(0.007)\end{array}$ & $\begin{array}{l}-0.011 \\
(0.008)\end{array}$ & $\begin{array}{l}-0.004 \\
(0.007)\end{array}$ & $\begin{array}{l}-0.012 \\
(0.007)\end{array}$ & $\begin{array}{l}-0.007 \\
(0.008)\end{array}$ & $\begin{array}{c}-0.013^{*} \\
(0.008)\end{array}$ \\
\hline Crisis & $\begin{array}{c}-0.027^{* * *} \\
(0.008)\end{array}$ & $\begin{array}{c}-0.025 * * * \\
(0.008)\end{array}$ & $\begin{array}{c}-0.025 * * * \\
(0.008)\end{array}$ & $\begin{array}{c}-0.022 * * * \\
(0.008)\end{array}$ & $\begin{array}{c}-0.026 * * * \\
(0.008)\end{array}$ & $\begin{array}{c}-0.025 * * * \\
(0.008)\end{array}$ & $\begin{array}{c}-0.036 * * * \\
(0.009)\end{array}$ & $\begin{array}{c}-0.034 * * * \\
(0.009)\end{array}$ \\
\hline Constant & $\begin{array}{c}0.044^{* * *} \\
(0.006)\end{array}$ & $\begin{array}{c}0.049 * * * \\
(0.006)\end{array}$ & $\begin{array}{c}0.048 * * * \\
(0.006)\end{array}$ & $\begin{array}{c}0.056 * * * \\
(0.006)\end{array}$ & $\begin{array}{c}0.051^{* * *} \\
(0.004)\end{array}$ & $\begin{array}{c}0.054^{* * *} \\
(0.004)\end{array}$ & $\begin{array}{c}0.071 * * * \\
(0.003)\end{array}$ & $\begin{array}{c}0.071 * * * \\
(0.003)\end{array}$ \\
\hline $\begin{array}{l}\text { Observations } \\
\text { Number of id }\end{array}$ & $\begin{array}{c}210 \\
9\end{array}$ & $\begin{array}{c}210 \\
9\end{array}$ & $\begin{array}{c}216 \\
9\end{array}$ & $\begin{array}{c}216 \\
9\end{array}$ & $\begin{array}{c}218 \\
9\end{array}$ & $\begin{array}{c}218 \\
9\end{array}$ & $\begin{array}{c}234 \\
9\end{array}$ & $\begin{array}{c}234 \\
9\end{array}$ \\
\hline $\begin{array}{l}\mathrm{R}^{2} \text { within } \\
\mathrm{R}^{2} \text { between } \\
\mathrm{R}^{2} \text { overall }\end{array}$ & $\begin{array}{l}0.534 \\
0.313 \\
0.481\end{array}$ & $\begin{array}{l}0.487 \\
0.526 \\
0.478\end{array}$ & $\begin{array}{l}0.509 \\
0.272 \\
0.456\end{array}$ & $\begin{array}{l}0.444 \\
0.383 \\
0.434\end{array}$ & $\begin{array}{l}0.526 \\
0.423 \\
0.500\end{array}$ & $\begin{array}{l}0.482 \\
0.509 \\
0.481\end{array}$ & $\begin{array}{l}0.284 \\
0.069 \\
0.250\end{array}$ & $\begin{array}{l}0.242 \\
0.128 \\
0.223\end{array}$ \\
\hline
\end{tabular}

Data source: IMF, national central banks. *Significant at the $10 \%$ level. ${ }^{* *}$ Significant at the $5 \%$ level. ***Significant at the $1 \%$ level. 
Table 7: GLS Estimation Results for East Asia and Latin America 1980 - 2005 (Dollar)

\begin{tabular}{|c|c|c|c|c|c|c|c|c|}
\hline & (1) & (2) & (3) & (4) & (5) & (6) & (7) & (8) \\
\hline Standard deviation & $\begin{array}{c}-0.097 * * * \\
(0.021)\end{array}$ & & $\begin{array}{c}-0.104^{* * *} \\
(0.021)\end{array}$ & & $\begin{array}{c}-0.051 * * * \\
(0.019)\end{array}$ & & $\begin{array}{c}-0.064 * * * \\
(0.019)\end{array}$ & \\
\hline Yearly change & $\begin{array}{c}0.003^{* * * *} \\
(0.001)\end{array}$ & & $\begin{array}{c}0.001^{* * *} \\
(0.000)\end{array}$ & & $\begin{array}{c}0.001 \\
(0.000)\end{array}$ & & $\begin{array}{c}0.000 \\
(0.000)\end{array}$ & \\
\hline Z-score & & $\begin{array}{c}-0.048 * * * \\
(0.017)\end{array}$ & & $\begin{array}{c}-0.032 * * * \\
(0.008)\end{array}$ & & $\begin{array}{c}-0.049 * * * \\
(0.017)\end{array}$ & & $\begin{array}{c}-0.044^{* * *} \\
(0.008)\end{array}$ \\
\hline Interest rate & $\begin{array}{c}-0.002 * * * \\
(0.000)\end{array}$ & $\begin{array}{c}-0.000 * * \\
(0.000)\end{array}$ & $\begin{array}{c}-0.001 * * * \\
(0.000)\end{array}$ & $\begin{array}{c}-0.000 * \\
(0.000)\end{array}$ & & & & \\
\hline Export growth & $\begin{array}{c}0.103^{* * *} \\
(0.013)\end{array}$ & $\begin{array}{c}0.099 * * * \\
(0.013)\end{array}$ & $\begin{array}{c}0.098 * * * \\
(0.013)\end{array}$ & $\begin{array}{c}0.099 * * * \\
(0.013)\end{array}$ & $\begin{array}{c}0.089 * * * \\
(0.012)\end{array}$ & $\begin{array}{c}0.087 * * * \\
(0.012)\end{array}$ & & \\
\hline Inflation & $\begin{array}{c}-0.002 * * * \\
(0.001)\end{array}$ & $\begin{array}{c}0.001 \\
(0.001)\end{array}$ & & & $\begin{array}{l}-0.001 \\
(0.001)\end{array}$ & $\begin{array}{c}0.000 \\
(0.001)\end{array}$ & & \\
\hline Inflation target & $\begin{array}{l}-0.011^{*} \\
(0.006)\end{array}$ & $\begin{array}{l}-0.009 \\
(0.006)\end{array}$ & $\begin{array}{l}-0.009 \\
(0.006)\end{array}$ & $\begin{array}{l}-0.009 \\
(0.006)\end{array}$ & $\begin{array}{l}-0.009 * \\
(0.006)\end{array}$ & $\begin{array}{l}-0.009 \\
(0.006)\end{array}$ & $\begin{array}{l}-0.007 \\
(0.007)\end{array}$ & $\begin{array}{l}-0.007 \\
(0.007)\end{array}$ \\
\hline Crisis & $\begin{array}{c}-0.031 * * * \\
(0.005)\end{array}$ & $\begin{array}{c}-0.031 * * * \\
(0.005)\end{array}$ & $\begin{array}{c}-0.030 * * * \\
(0.005)\end{array}$ & $\begin{array}{c}-0.032 * * * \\
(0.005)\end{array}$ & $\begin{array}{c}-0.029 * * * \\
(0.005)\end{array}$ & $\begin{array}{c}-0.030 * * * \\
(0.005)\end{array}$ & $\begin{array}{c}-0.032 * * * \\
(0.004)\end{array}$ & $\begin{array}{c}-0.033 * * * \\
(0.005)\end{array}$ \\
\hline Constant & $\begin{array}{c}0.044 * * * \\
(0.003)\end{array}$ & $\begin{array}{c}0.043 * * * \\
(0.003)\end{array}$ & $\begin{array}{c}0.045^{* * *} \\
(0.003)\end{array}$ & $\begin{array}{c}0.043 * * * \\
(0.003)\end{array}$ & $\begin{array}{c}0.043^{* * *} \\
(0.003)\end{array}$ & $\begin{array}{c}0.043 * * * \\
(0.003)\end{array}$ & $\begin{array}{c}0.054 * * * \\
(0.002)\end{array}$ & $\begin{array}{c}0.054^{* * *} \\
(0.002)\end{array}$ \\
\hline Observations & 418 & 418 & 424 & 424 & 448 & 448 & 470 & 470 \\
\hline Number of id & 19 & 19 & 19 & 19 & 19 & 19 & 19 & 19 \\
\hline $\mathrm{R}^{2}$ within & 0.305 & 0.272 & 0.286 & 0.265 & 0.253 & 0.255 & 0.141 & 0.143 \\
\hline $\mathrm{R}^{2}$ between & 0.708 & 0.782 & 0.749 & 0.753 & 0.753 & 0.769 & 0.628 & 0.624 \\
\hline $\mathrm{R}^{2}$ overall & 0.357 & 0.324 & 0.338 & 0.318 & 0.303 & 0.306 & 0.195 & 0.199 \\
\hline
\end{tabular}

Data source: IMF, national central banks. *Significant at the $10 \%$ level. **Significant at the $5 \%$ level. ***Significant at the $1 \%$ level. 
Table 8: GMM - Two Step Estimation Results for East Asia and Latin America 1986 - 2005 (Dollar)

\begin{tabular}{|c|c|c|c|c|c|c|c|c|}
\hline & (1) & (2) & (3) & (4) & (5) & (6) & (7) & (8) \\
\hline Growth & $\begin{array}{l}0.349 * \\
(0.187)\end{array}$ & $\begin{array}{c}0.171 \\
(0.131)\end{array}$ & $\begin{array}{c}0.169 * * \\
(0.085)\end{array}$ & $\begin{array}{c}0.181^{* * *} \\
(0.027)\end{array}$ & $\begin{array}{l}0.172 * \\
(0.104)\end{array}$ & $\begin{array}{c}0.169 * * * \\
(0.022)\end{array}$ & $\begin{array}{c}0.283 * * * \\
(0.089)\end{array}$ & $\begin{array}{c}0.241^{* * *} \\
(0.077)\end{array}$ \\
\hline Standard deviation & $\begin{array}{c}-0.267^{*} \\
(0.142)\end{array}$ & & $\begin{array}{c}-0.125 * * * \\
(0.009)\end{array}$ & & $\begin{array}{l}-0.105^{*} \\
(0.059)\end{array}$ & & $\begin{array}{c}-0.104 * * * \\
(0.027)\end{array}$ & \\
\hline Yearly change & $\begin{array}{c}0.003 * * * \\
(0.001)\end{array}$ & & $\begin{array}{c}0.001^{* * *} \\
(0.000)\end{array}$ & & $\begin{array}{c}0.001 \\
(0.001)\end{array}$ & & $\begin{array}{c}0.001 * * * \\
(0.000)\end{array}$ & \\
\hline Z-score & & $\begin{array}{l}-0.146 \\
(0.116)\end{array}$ & & $\begin{array}{c}-0.091 * * * \\
(0.007)\end{array}$ & & $\begin{array}{l}-0.106 \\
(0.069)\end{array}$ & & $\begin{array}{c}-0.059 * * * \\
(0.021)\end{array}$ \\
\hline Interest rate & $\begin{array}{c}-0.001^{* * *} \\
(0.000)\end{array}$ & $\begin{array}{c}0.000 \\
(0.001)\end{array}$ & $\begin{array}{c}-0.001 * * * \\
(0.000)\end{array}$ & $\begin{array}{c}0.000 * * * \\
(0.000)\end{array}$ & & & & \\
\hline Export growth & $\begin{array}{c}0.111^{* * * *} \\
(0.029)\end{array}$ & $\begin{array}{c}0.095 * * * \\
(0.026)\end{array}$ & $\begin{array}{c}0.099 * * * \\
(0.002)\end{array}$ & $\begin{array}{c}0.099 * * * \\
(0.002)\end{array}$ & $\begin{array}{c}0.099 * * * \\
(0.023)\end{array}$ & $\begin{array}{c}0.096 * * * \\
(0.005)\end{array}$ & & \\
\hline Inflation & $\begin{array}{c}0.000 \\
(0.002)\end{array}$ & $\begin{array}{c}0.001 \\
(0.001)\end{array}$ & & & $\begin{array}{l}-0.000 \\
(0.003)\end{array}$ & $\begin{array}{c}0.001 \\
(0.002)\end{array}$ & & \\
\hline Inflation target & $\begin{array}{c}-0.008 \\
(0.013)\end{array}$ & $\begin{array}{c}0.001 \\
(0.012)\end{array}$ & $\begin{array}{c}0.002 \\
(0.012)\end{array}$ & $\begin{array}{c}0.004 \\
(0.016)\end{array}$ & $\begin{array}{c}0.004 \\
(0.013)\end{array}$ & $\begin{array}{c}0.004 \\
(0.012)\end{array}$ & $\begin{array}{c}0.012 \\
(0.016)\end{array}$ & $\begin{array}{c}0.018 \\
(0.016)\end{array}$ \\
\hline Crisis & $\begin{array}{c}-0.024^{* * *} \\
(0.006)\end{array}$ & $\begin{array}{c}-0.026 * * * \\
(0.005)\end{array}$ & $\begin{array}{c}-0.024^{* * *} \\
(0.003)\end{array}$ & $\begin{array}{c}-0.025 * * * \\
(0.003)\end{array}$ & $\begin{array}{c}-0.026 * * * \\
(0.013)\end{array}$ & $\begin{array}{c}-0.026 * * * \\
(0.003)\end{array}$ & $\begin{array}{c}-0.027 * * * \\
(0.004)\end{array}$ & $\begin{array}{c}-0.026 * * * \\
(0.001)\end{array}$ \\
\hline Constant & $\begin{array}{c}-0.002 * * * \\
(0.001)\end{array}$ & $\begin{array}{c}-0.001^{* *} \\
(0.001)\end{array}$ & $\begin{array}{c}-0.001 * * * \\
(0.000)\end{array}$ & $\begin{array}{c}-0.001 * * * \\
(0.000)\end{array}$ & $\begin{array}{c}-0.001 * * * \\
(0.000)\end{array}$ & $\begin{array}{c}-0.001 * * * \\
(0.000)\end{array}$ & $\begin{array}{c}-0.001 * * * \\
(0.000)\end{array}$ & $\begin{array}{c}-0.001 * * * \\
(0.000)\end{array}$ \\
\hline Observations & 331 & 331 & 331 & 331 & 338 & 338 & 338 & 338 \\
\hline Number of id & 19 & 19 & 19 & 19 & 19 & 19 & 19 & 19 \\
\hline Sargan test Chi ${ }^{2}$ & 11.56 & 13.56 & 12.84 & 13.15 & 13.56 & 13.56 & 15.82 & 16.30 \\
\hline Prob $>\mathrm{Chi}^{2}$ & 1.000 & 1.000 & 1.000 & 1.000 & 1.000 & 1.000 & 1.000 & 1.000 \\
\hline $\operatorname{AR}(2)$ & 0.175 & 0.246 & 0.090 & 0.114 & 0.071 & 0.117 & 0.042 & 0.043 \\
\hline
\end{tabular}

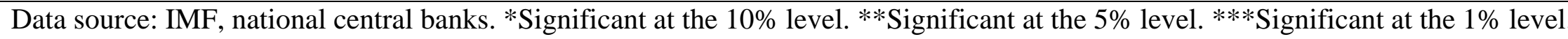


Table 9: GLS Estimation Results for Emerging Europe (Euro) and East Asia (Dollar) 1994 - 2005

\begin{tabular}{|c|c|c|c|c|c|c|c|c|}
\hline & (1) & (2) & (3) & (4) & (5) & (6) & (7) & (8) \\
\hline Standard deviation & $\begin{array}{c}-0.514^{* * * *} \\
(0.082)\end{array}$ & & $\begin{array}{c}-0.609 * * * \\
(0.073)\end{array}$ & & $\begin{array}{c}-0.509 * * * \\
(0.082)\end{array}$ & & $\begin{array}{c}-0.261 * * * \\
(0.057)\end{array}$ & \\
\hline Yearly change & $\begin{array}{c}0.003 \\
(0.008)\end{array}$ & & $\begin{array}{c}0.011 \\
(0.007)\end{array}$ & & $\begin{array}{l}-0.012^{*} \\
(0.006)\end{array}$ & & $\begin{array}{c}-0.014 * * \\
(0.007)\end{array}$ & \\
\hline Z-score & & $\begin{array}{c}-0.478 * * * \\
(0.071)\end{array}$ & & $\begin{array}{c}-0.547 * * * \\
(0.069)\end{array}$ & & $\begin{array}{c}-0.553 * * * \\
(0.067)\end{array}$ & & $\begin{array}{c}-0.312 * * * \\
(0.043)\end{array}$ \\
\hline Interest rate & $\begin{array}{c}-0.061 * * * \\
(0.021)\end{array}$ & $\begin{array}{c}-0.045^{* * *} \\
(0.016)\end{array}$ & $\begin{array}{c}-0.090^{* * *} \\
(0.017)\end{array}$ & $\begin{array}{c}-0.064 * * * \\
(0.015)\end{array}$ & & & & \\
\hline Export growth & $\begin{array}{c}0.067 * * * \\
(0.011)\end{array}$ & $\begin{array}{c}0.071 * * * \\
(0.011)\end{array}$ & $\begin{array}{c}0.040 * * * \\
(0.006)\end{array}$ & $\begin{array}{c}0.039 * * * \\
(0.058)\end{array}$ & $\begin{array}{c}0.081^{* * *} \\
(0.009)\end{array}$ & $\begin{array}{c}0.080 * * * \\
(0.009)\end{array}$ & & \\
\hline Inflation & $\begin{array}{c}-0.028 * * * \\
(0.011)\end{array}$ & $\begin{array}{c}-0.033 * * * \\
(0.010)\end{array}$ & & & $\begin{array}{c}-0.041^{* * *} \\
(0.009)\end{array}$ & $\begin{array}{c}-0.038^{* * * *} \\
(0.009)\end{array}$ & & \\
\hline Inflation target & $\begin{array}{c}-0.013^{* *} \\
(0.006)\end{array}$ & $\begin{array}{c}-0.012 * * \\
(0.006)\end{array}$ & $\begin{array}{c}-0.016 * * \\
(0.006)\end{array}$ & $\begin{array}{c}-0.015 * * \\
(0.006)\end{array}$ & $\begin{array}{l}-0.009 \\
(0.006)\end{array}$ & $\begin{array}{l}-0.009 \\
(0.006)\end{array}$ & $\begin{array}{l}-0.011 \\
(0.007)\end{array}$ & $\begin{array}{l}-0.010 \\
(0.007)\end{array}$ \\
\hline Crisis & $\begin{array}{l}-0.004 \\
(0.004)\end{array}$ & $\begin{array}{l}-0.004 \\
(0.004)\end{array}$ & $\begin{array}{l}-0.004 \\
(0.004)\end{array}$ & $\begin{array}{l}-0.005 \\
(0.004)\end{array}$ & $\begin{array}{l}-0.004 \\
(0.004)\end{array}$ & $\begin{array}{l}-0.004 \\
(0.004)\end{array}$ & $\begin{array}{c}-0.012 * * * \\
(0.004)\end{array}$ & $\begin{array}{c}-0.012 * * * \\
(0.004)\end{array}$ \\
\hline Constant & $\begin{array}{c}0.056 * * * \\
(0.004)\end{array}$ & $\begin{array}{c}0.055 * * * \\
(0.003)\end{array}$ & $\begin{array}{c}0.062 * * * \\
(0.003)\end{array}$ & $\begin{array}{c}0.059 * * * \\
(0.003)\end{array}$ & $\begin{array}{c}0.049 * * * \\
(0.003)\end{array}$ & $\begin{array}{c}0.049 * * * \\
(0.003)\end{array}$ & $\begin{array}{c}0.055 * * * \\
(0.003)\end{array}$ & $\begin{array}{c}0.055^{* * *} \\
(0.003)\end{array}$ \\
\hline $\begin{array}{l}\text { Observations } \\
\text { Number of id }\end{array}$ & $\begin{array}{c}288 \\
25\end{array}$ & $\begin{array}{c}288 \\
25\end{array}$ & $\begin{array}{c}292 \\
26\end{array}$ & $\begin{array}{c}292 \\
26\end{array}$ & $\begin{array}{c}300 \\
25\end{array}$ & $\begin{array}{c}300 \\
25\end{array}$ & $\begin{array}{c}308 \\
26\end{array}$ & $\begin{array}{c}308 \\
26\end{array}$ \\
\hline $\mathrm{R}^{2}$ within & 0.426 & 0.425 & 0.409 & 0.397 & 0.398 & 0.399 & 0.193 & 0.188 \\
\hline $\mathrm{R}^{2}$ between & 0.279 & 0.282 & 0.269 & 0.275 & 0.182 & 0.161 & 0.252 & 0.234 \\
\hline $\mathrm{R}^{2}$ overall & 0.354 & 0.354 & 0.328 & 0.326 & 0.346 & 0.338 & 0.201 & 0.194 \\
\hline
\end{tabular}

Data source: IMF, national central banks. *Significant at the $10 \%$ level. **Significant at the $5 \%$ level. ***Significant at the $1 \%$ level. 
Table 10: GMM - Two Step Estimation Results for Emerging Europe (Euro) and East Asia (Dollar) 1994 - 2005

\begin{tabular}{|c|c|c|c|c|c|c|c|c|}
\hline & (1) & (2) & (3) & (4) & (5) & (6) & (7) & (8) \\
\hline Growth & $\begin{array}{c}0.384 \\
(0.058)\end{array}$ & $\begin{array}{c}0.109 * * * \\
(0.028)\end{array}$ & $\begin{array}{c}0.013 \\
(0.070)\end{array}$ & $\begin{array}{l}0.062 * \\
(0.034)\end{array}$ & $\begin{array}{c}0.113^{* * *} \\
(0.033)\end{array}$ & $\begin{array}{c}0.106^{* * *} \\
(0.027)\end{array}$ & $\begin{array}{c}0.203^{* * *} \\
(0.038)\end{array}$ & $\begin{array}{c}0.178 * * * \\
(0.042)\end{array}$ \\
\hline Standard deviation & $\begin{array}{c}-0.588 * * * \\
(0.174)\end{array}$ & & $\begin{array}{c}-0.665 * * * \\
(0.103)\end{array}$ & & $\begin{array}{c}-0.435 * * * \\
(0.167)\end{array}$ & & $\begin{array}{c}-0.358 * * * \\
(0.072)\end{array}$ & \\
\hline Yearly change & $\begin{array}{c}0.019 \\
(0.012)\end{array}$ & & $\begin{array}{c}0.024^{* * *} \\
(0.007)\end{array}$ & & $\begin{array}{c}-0.028 * * * \\
(0.006)\end{array}$ & & $\begin{array}{c}-0.009 * * * \\
(0.002)\end{array}$ & \\
\hline Z-score & & $\begin{array}{c}-0.481^{* * *} \\
(0.142)\end{array}$ & & $\begin{array}{c}-0.674 * * * \\
(0.082)\end{array}$ & & $\begin{array}{c}-0.706 * * * \\
(0.086)\end{array}$ & & $\begin{array}{c}-0.257 * * * \\
(0.026)\end{array}$ \\
\hline Interest rate & $\begin{array}{c}-0.155^{* * *} \\
(0.056)\end{array}$ & $\begin{array}{c}-0.123 * * * \\
(0.044)\end{array}$ & $\begin{array}{c}-0.156 * * * \\
(0.036)\end{array}$ & $\begin{array}{c}-0.079 * * * \\
(0.014)\end{array}$ & & & & \\
\hline Export growth & $\begin{array}{c}0.084 * * * \\
(0.010)\end{array}$ & $\begin{array}{c}0.099 * * * \\
(0.009)\end{array}$ & $\begin{array}{c}0.044^{* * * *} \\
(0.008)\end{array}$ & $\begin{array}{c}0.049 * * * \\
(0.006)\end{array}$ & $\begin{array}{c}0.104^{* * * *} \\
(0.012)\end{array}$ & $\begin{array}{c}0.096 * * * \\
(0.013)\end{array}$ & & \\
\hline Inflation & $\begin{array}{c}-0.038 * * * \\
(0.013)\end{array}$ & $\begin{array}{c}-0.051^{* * *} \\
(0.010)\end{array}$ & & & $\begin{array}{c}-0.064^{* * *} \\
(0.014)\end{array}$ & $\begin{array}{c}-0.042 * * * \\
(0.014)\end{array}$ & & \\
\hline Inflation target & $\begin{array}{l}-0.002 \\
(0.014)\end{array}$ & $\begin{array}{c}0.003 \\
(0.013)\end{array}$ & $\begin{array}{l}-0.005 \\
(0.010)\end{array}$ & $\begin{array}{l}-0.007 \\
(0.012)\end{array}$ & $\begin{array}{c}0.010 \\
(0.013)\end{array}$ & $\begin{array}{c}0.004 \\
(0.013)\end{array}$ & $\begin{array}{c}-0.009 \\
(0.009)\end{array}$ & $\begin{array}{l}-0.009 \\
(0.010)\end{array}$ \\
\hline Crisis & $\begin{array}{c}-0.003 * \\
(0.002)\end{array}$ & $\begin{array}{c}-0.006 * * * \\
(0.002)\end{array}$ & $\begin{array}{c}-0.004 * * \\
(0.002)\end{array}$ & $\begin{array}{l}-0.003 \\
(0.002)\end{array}$ & $\begin{array}{c}-0.005^{* * *} \\
(0.002)\end{array}$ & $\begin{array}{c}-0.004 * * \\
(0.002)\end{array}$ & $\begin{array}{c}-0.011 * * * \\
(0.001)\end{array}$ & $\begin{array}{c}-0.012 * * * \\
(0.001)\end{array}$ \\
\hline Constant & $\begin{array}{c}-0.003 * * * \\
(0.001)\end{array}$ & $\begin{array}{c}-0.003 * * * \\
(0.001)\end{array}$ & $\begin{array}{c}-0.002 * * * \\
(0.001)\end{array}$ & $\begin{array}{c}-0.002 * * * \\
(0.000)\end{array}$ & $\begin{array}{c}-0.002 * * * \\
(0.001)\end{array}$ & $\begin{array}{c}-0.001 * * * \\
(0.005)\end{array}$ & $\begin{array}{c}-0.000 \\
(0.000)\end{array}$ & $\begin{array}{l}-0.000 \\
(0.000)\end{array}$ \\
\hline Observations & 241 & 241 & 243 & 243 & 250 & 250 & 257 & 257 \\
\hline Number of id & 25 & 25 & 26 & 26 & 25 & 25 & 26 & 26 \\
\hline Sargan test Chi² & 19.81 & 18.78 & 24.26 & 22.35 & 17.72 & 18.66 & 20.47 & 23.89 \\
\hline Prob $>$ Chi $^{2}$ & 1.000 & 1.000 & 1.000 & 1.000 & 1.000 & 1.000 & 1.000 & 1.000 \\
\hline $\operatorname{AR}(2)$ & 0.959 & 0.529 & 0.700 & 0.877 & 0.486 & 0.559 & 0.990 & 0.996 \\
\hline
\end{tabular}

Data source: IMF, national central banks. *Significant at the $10 \%$ level. ${ }^{* *}$ Significant at the $5 \%$ level. $* * *$ Significant at the $1 \%$ level. 


\section{CESifo Working Paper Series}

(for full list see www.cesifo-group.de)

1956 Panu Poutvaara and Lars-H. R. Siemers, Smoking and Social Interaction, March 2007

1957 Stephan Danninger and Fred Joutz, What Explains Germany's Rebounding Export Market Share?, March 2007

1958 Stefan Krasa and Mattias Polborn, Majority-efficiency and Competition-efficiency in a Binary Policy Model, March 2007

1959 Thiess Buettner and Georg Wamser, Intercompany Loans and Profit Shifting Evidence from Company-Level Data, March 2007

1960 Per Pettersson-Lidbom and Mikael Priks, Behavior under Social Pressure: Empty Italian Stadiums and Referee Bias, April 2007

1961 Balázs Égert and Carol S. Leonard, Dutch Disease Scare in Kazakhstan: Is it real?, April 2007

1962 Paul De Grauwe and Pablo Rovira Kaltwasser, Modeling Optimism and Pessimism in the Foreign Exchange Market, April 2007

1963 Volker Grossmann and Thomas M. Steger, Anti-Competitive Conduct, In-House R\&D, and Growth, April 2007

1964 Steven Brakman and Charles van Marrewijk, It's a Big World After All, April 2007

1965 Mauro Ghinamo, Paolo M. Panteghini and Federico Revelli, FDI Determination and Corporate Tax Competition in a Volatile World, April 2007

1966 Inés Macho-Stadler and David Pérez-Castrillo, Optimal Monitoring to Implement Clean Technologies when Pollution is Random, April 2007

1967 Thomas Eichner and Ruediger Pethig, Efficient $\mathrm{CO}_{2}$ Emissions Control with National Emissions Taxes and International Emissions Trading, April 2007

1968 Michela Redoano, Does Centralization Affect the Number and Size of Lobbies?, April 2007

1969 Christian Gollier, Intergenerational Risk-Sharing and Risk-Taking of a Pension Fund, April 2007

1970 Swapan K. Bhattacharya and Biswa N. Bhattacharyay, Gains and Losses of India-China Trade Cooperation - a Gravity Model Impact Analysis, April 2007

1971 Gerhard Illing, Financial Stability and Monetary Policy - A Framework, April 2007 
1972 Rainald Borck and Matthias Wrede, Commuting Subsidies with two Transport Modes, April 2007

1973 Frederick van der Ploeg, Prudent Budgetary Policy: Political Economy of Precautionary Taxation, April 2007

1974 Ben J. Heijdra and Ward E. Romp, Retirement, Pensions, and Ageing, April 2007

1975 Scott Alan Carson, Health during Industrialization: Evidence from the $19^{\text {th }}$ Century Pennsylvania State Prison System, April 2007

1976 Andreas Haufler and Ian Wooton, Competition for Firms in an Oligopolistic Industry: Do Firms or Countries Have to Pay?, April 2007

1977 Eckhard Janeba, Exports, Unemployment and the Welfare State, April 2007

1978 Gernot Doppelhofer and Melvyn Weeks, Jointness of Growth Determinants, April 2007

1979 Edith Sand and Assaf Razin, The Role of Immigration in Sustaining the Social Security System: A Political Economy Approach, April 2007

1980 Marco Pagano and Giovanni Immordino, Optimal Regulation of Auditing, May 2007

1981 Ludger Woessmann, Fundamental Determinants of School Efficiency and Equity: German States as a Microcosm for OECD Countries, May 2007

1982 Bas Jacobs, Real Options and Human Capital Investment, May 2007

1983 Steinar Holden and Fredrik Wulfsberg, Are Real Wages Rigid Downwards?, May 2007

1984 Cheng Hsiao, M. Hashem Pesaran and Andreas Pick, Diagnostic Tests of Cross Section Independence for Nonlinear Panel Data Models, May 2007

1985 Luis Otávio Façanha and Marcelo Resende, Hierarchical Structure in Brazilian Industrial Firms: An Econometric Study, May 2007

1986 Ondřej Schneider, The EU Budget Dispute - A Blessing in Disguise?, May2007

1987 Sascha O. Becker and Ludger Woessmann, Was Weber Wrong? A Human Capital Theory of Protestant Economic History, May 2007

1988 Erkki Koskela and Rune Stenbacka, Equilibrium Unemployment with Outsourcing and Wage Solidarity under Labour Market Imperfections, May 2007

1989 Guglielmo Maria Caporale, Juncal Cunado and Luis A. Gil-Alana, Deterministic versus Stochastic Seasonal Fractional Integration and Structural Breaks, May 2007

1990 Cláudia Costa Storti and Paul De Grauwe, Globalization and the Price Decline of Illicit Drugs, May 2007 
1991 Thomas Eichner and Ruediger Pethig, Pricing the Ecosystem and Taxing Ecosystem Services: A General Equilibrium Approach, May 2007

1992 Wladimir Raymond, Pierre Mohnen, Franz Palm and Sybrand Schim van der Loeff, The Behavior of the Maximum Likelihood Estimator of Dynamic Panel Data Sample Selection Models, May 2007

1993 Fahad Khalil, Jacques Lawarrée and Sungho Yun, Bribery vs. Extortion: Allowing the Lesser of two Evils, May 2007

1994 Thorvaldur Gylfason, The International Economics of Natural Resources and Growth, May 2007

1995 Catherine Roux and Thomas von Ungern-Sternberg, Leniency Programs in a Multimarket Setting: Amnesty Plus and Penalty Plus, May 2007

1996 J. Atsu Amegashie, Bazoumana Ouattara and Eric Strobl, Moral Hazard and the Composition of Transfers: Theory with an Application to Foreign Aid, May 2007

1997 Wolfgang Buchholz and Wolfgang Peters, Equal Sacrifice and Fair Burden Sharing in a Public Goods Economy, May 2007

1998 Robert S. Chirinko and Debdulal Mallick, The Fisher/Cobb-Douglas Paradox, Factor Shares, and Cointegration, May 2007

1999 Petra M. Geraats, Political Pressures and Monetary Mystique, May 2007

2000 Hartmut Egger and Udo Kreickemeier, Firm Heterogeneity and the Labour Market Effects of Trade Liberalisation, May 2007

2001 Andreas Freytag and Friedrich Schneider, Monetary Commitment, Institutional Constraints and Inflation: Empirical Evidence for OECD Countries since the 1970s, May 2007

2002 Niclas Berggren, Henrik Jordahl and Panu Poutvaara, The Looks of a Winner: Beauty, Gender, and Electoral Success, May 2007

2003 Tomer Blumkin, Yoram Margalioth and Efraim Sadka, Incorporating Affirmative Action into the Welfare State, May 2007

2004 Harrie A. A. Verbon, Migrating Football Players, Transfer Fees and Migration Controls, May 2007

2005 Helmuth Cremer, Jean-Marie Lozachmeur and Pierre Pestieau, Income Taxation of Couples and the Tax Unit Choice, May 2007

2006 Michele Moretto and Paolo M. Panteghini, Preemption, Start-Up Decisions and the Firms' Capital Structure, May 2007 
2007 Andreas Schäfer and Thomas M. Steger, Macroeconomic Consequences of Distributional Conflicts, May 2007

2008 Mikael Priks, Judiciaries in Corrupt Societies, June 2007

2009 Steinar Holden and Fredrik Wulfsberg, Downward Nominal Wage Rigidity in the OECD, June 2007

2010 Emmanuel Dhyne, Catherine Fuss, Hashem Pesaran and Patrick Sevestre, Lumpy Price Adjustments: A Microeconometric Analysis, June 2007

2011 Paul Belleflamme and Eric Toulemonde, Negative Intra-Group Externalities in TwoSided Markets, June 2007

2012 Carlos Alós-Ferrer, Georg Kirchsteiger and Markus Walzl, On the Evolution of Market Institutions: The Platform Design Paradox, June 2007

2013 Axel Dreher and Martin Gassebner, Greasing the Wheels of Entrepreneurship? The Impact of Regulations and Corruption on Firm Entry, June 2007

2014 Dominique Demougin and Claude Fluet, Rules of Proof, Courts, and Incentives, June 2007

2015 Stefan Lachenmaier and Horst Rottmann, Effects of Innovation on Employment: A Dynamic Panel Analysis, June 2007

2016 Torsten Persson and Guido Tabellini, The Growth Effect of Democracy: Is it Heterogenous and how can it be Estimated?, June 2007

2017 Lorenz Blume, Jens Müller, Stefan Voigt and Carsten Wolf, The Economic Effects of Constitutions: Replicating - and Extending - Persson and Tabellini, June 2007

2018 Hartmut Egger and Gabriel Felbermayr, Endogenous Skill Formation and the Source Country Effects of International Labor Market Integration, June 2007

2019 Bruno Frey, Overprotected Politicians, June 2007

2020 Jan Thomas Martini, Rainer Niemann and Dirk Simons, Transfer Pricing or Formula Apportionment? Tax-Induced Distortions of Multinationals' Investment and Production Decisions, June 2007

2021 Andreas Bühn, Alexander Karmann and Friedrich Schneider, Size and Development of the Shadow Economy and of Do-it-yourself Activities in Germany, June 2007

2022 Michael Rauscher and Edward B. Barbier, Biodiversity and Geography, June 2007

2023 Gunther Schnabl, Exchange Rate Volatility and Growth in Emerging Europe and East Asia, June 2007 